\title{
Polar MM5 Simulations of the Winter Climate of the Laurentide Ice Sheet at the $\mathbf{L G M}^{*}$
}

\author{
DAVID H. BROMWICH \\ Polar Meteorology Group, Byrd Polar Research Center, and Atmospheric Sciences Program, Department of Geography, \\ The Ohio State University, Columbus, Ohio

\section{E. RICHARD TORACINTA} \\ Polar Meteorology Group, Byrd Polar Research Center, The Ohio State University, Columbus, Ohio \\ HELIN WeI \\ National Centers for Environmental Prediction, Camp Springs, Maryland \\ Robert J. OGLesby \\ NASA Marshall Space Flight Center/National Space Science and Technology Center, Huntsville, Alabama \\ JAmes L. FAstook AND Terence J. Hughes \\ Institute for Quaternary and Climate Studies, University of Maine, Orono, Maine
}

(Manuscript received 21 November 2003, in final form 4 March 2004)

\section{ABSTRACT}

\begin{abstract}
Optimized regional climate simulations are conducted using the Polar MM5, a version of the fifth-generation Pennsylvania State University-NCAR Mesoscale Model (MM5), with a 60-km horizontal resolution domain over North America during the Last Glacial Maximum (LGM, 21000 calendar years ago), when much of the continent was covered by the Laurentide Ice Sheet (LIS). The objective is to describe the LGM annual cycle at high spatial resolution with an emphasis on the winter atmospheric circulation. Output from a tailored NCAR Community Climate Model version 3 (CCM3) simulation of the LGM climate is used to provide the initial and lateral boundary conditions for Polar MM5. LGM boundary conditions include continental ice sheets, appropriate orbital forcing, reduced $\mathrm{CO}_{2}$ concentration, paleovegetation, modified sea surface temperatures, and lowered sea level.

Polar MM5 produces a substantially different atmospheric response to the LGM boundary conditions than CCM3 and other recent GCM simulations. In particular, from November to April the upper-level flow is split around a blocking anticyclone over the LIS, with a northern branch over the Canadian Arctic and a southern branch impacting southern North America. The split flow pattern is most pronounced in January and transitions into a single, consolidated jet stream that migrates northward over the LIS during summer. Sensitivity experiments indicate that the winter split flow in Polar MM5 is primarily due to mechanical forcing by LIS, although model physics and resolution also contribute to the simulated flow configuration.

Polar MM5 LGM results are generally consistent with proxy climate estimates in the western United States, Alaska, and the Canadian Arctic and may help resolve some long-standing discrepancies between proxy data and previous simulations of the LGM climate.
\end{abstract}

\section{Introduction}

In the effort to better understand possible climate change mechanisms, particular attention has been given to the Last

* Byrd Polar Research Center Contribution Number 1290.

Corresponding author address: Dr. David Bromwich, Byrd Polar Research Center, The Ohio State University, 1090 Carmack Road, Columbus, OH 43210-1002.

E-mail: bromwich@polarmet1.mps.ohio-state.edu
Glacial Maximum (LGM), approximately 21000 calendar years before present (21 kyr BP). The climate forcing mechanisms at the LGM, including reduced trace gas concentrations, cooler ocean temperatures, orbital configuration, changes in vegetation patterns, and Northern Hemisphere continental-scale ice sheets, combined to maintain a much cooler global climate than now present. In particular, the Laurentide and Fennoscandian Ice Sheets, which covered much of North America and Scandinavia, respectively, contributed to a higher planetary albedo and, 
at $2-3-\mathrm{km}$ elevation, would have represented formidable obstacles in the Northern Hemisphere westerly flow. At the LGM, the Laurentide Ice Sheet, for instance, had spatial dimensions similar to contemporary Antarctica. The influence of the ice sheets on the atmospheric standing wave pattern would likely have had a first-order impact on the distributions of temperature and precipitation both proximate to and downstream of the ice sheets, just as the Tibetan Plateau influences the contemporary Northern Hemisphere atmospheric circulation. Hence, an accurate representation of the LGM climate requires, among other things, an accurate treatment of the continental ice sheets.

Previous studies have primarily used atmospheric global climate models (GCMs) to simulate the LGM climate, and several of these studies have focused on the influence of the Northern Hemisphere ice sheetsparticularly the Laurentide-on the atmospheric circulation. In an early GCM study, Manabe and Broccoli (1985) indicate that the Northern Hemisphere midlatitude westerlies split into two distinct branches straddling the Laurentide Ice Sheet. The northern branch of the split jet maintained strong cold air advection over eastern Canada and the North Atlantic, while cyclones developing along the southern branch were responsible for enhanced precipitation along the southeastern Laurentide Ice Sheet margin. Several other GCM studies of the LGM climate (e.g., Kutzbach and Wright 1985; Rind 1987; Shinn and Barron 1989) have obtained similar configurations of the Northern Hemisphere jet stream. Cook and Held (1988) use a linear primitive equation model to demonstrate that the Northern Hemisphere stationary wave pattern (and the split North American jet stream) at the LGM is largely due to direct mechanical forcing by the Laurentide Ice Sheet rather than changes in diabatic heating or heat and momentum contributions from transient eddies.

In contrast, a number of recent GCM studies of the LGM show little or no indication of a split upper-level jet stream over the Laurentide Ice Sheet (Felzer et al. 1996; Hall et al. 1996; Kageyama and Valdes 2000; Toracinta et al. 2004). Rather, in these studies the Laurentide Ice Sheet induces an enhanced upstream ridge/ downstream trough pattern with flow diverted up and over the ice sheet similar to the "small mountain" flow regime (Kageyama and Valdes 2000). Roe and Lindzen (2001) note that, in addition to orographic effects, a continental ice sheet represents a source of thermal forcing that, if large enough, would induce feedbacks that could also alter the atmospheric circulation. Because the atmosphere and the ice sheets represent a coupled system, growth or decay of the ice sheet in turn depends strongly on the configuration of the atmospheric circulation pattern.

Although atmospheric GCMs are generally well suited for global simulations of the LGM climate, early GCMs had coarse spatial resolution (e.g., $8^{\circ}$ latitude $X$ $10^{\circ}$ longitude), which could contribute to an inaccurate representation of important large-scale features such as the atmospheric long-wave pattern and storm tracks (Shinn and Barron 1989; Dong and Valdes 2000). However, even at the finest currently available resolution (typically $2.8^{\circ}$ latitude-longitude grid), GCMs may not capture important mesoscale processes associated with large ice sheets (e.g., katabatic winds). Regional atmospheric models, with high spatial resolution and multiple options for physical parameterizations, are being more frequently used for climate applications. Among these models is Polar MM5, a version of the fifth-generation Pennsylvania State University-National Center for Atmospheric Research (PSU-NCAR) Mesoscale Model (MM5; Dudhia 1993; Grell et al. 1994) adapted specifically for simulations over polar regions (Bromwich et al. 2001; Cassano et al. 2001). The Polar MM5 has been tested extensively over present-day Greenland (Bromwich et al. 2001; Cassano et al. 2001) and Antarctica (Bromwich et al. 2003; Guo et al. 2003) and currently provides real-time numerical weather prediction in support of U.S. aircraft operations in Antarctica via the Antarctic Mesoscale Prediction System (AMPS; Powers et al. 2003). Contemporary Greenland and Antarctica likely represent the range of conditions that existed over the Laurentide Ice Sheet at the LGM and serve as reasonable analogs. Hence, Polar MM5 is well suited for simulations over the Laurentide Ice Sheet.

In simulations of the contemporary climate, others have demonstrated that results from a regional climate model coupled to a GCM are more realistic than those from the GCM alone (Giorgi et al. 1990; Ji and Vernekar 1997). In the present study, Polar MM5 is coupled to the NCAR Community Climate Model version 3 (CCM3; Kiehl et al. 1998) for simulations of the LGM climate over the Laurentide Ice Sheet. We extend the work of previous GCM studies of the LGM climate and the impact of the continental ice sheets on the atmospheric circulation by using a high-resolution regional climate model that is known to perform well over continental-scale ice sheets. Our objective is to describe the annual cycle of the climate at the LGM with specific attention on the winter atmospheric circulation. As in previous GCM simulations, we also investigate through sensitivity tests the effects of ice sheet height as well as model physics on the wintertime circulation.

Section 2 briefly describes the Polar MM5, the LGM boundary conditions, and the approach used for the model experiments. Section 3 presents results from a full annual cycle of the LGM climate from Polar MM5 along with results from several sensitivity tests for the winter climate. A discussion follows in section 4 with concluding statements in section 5 .

\section{Data and methods}

\section{a. Polar MM5 physics and LGM domain}

The Polar MM5 in the current study is a nonhydrostatic three-dimensional atmospheric model based on 
MM5 version 3.4. While Bromwich et al. (2001) and Cassano et al. (2001) provide details of the optimized polar physics, a brief summary of these is presented here along with the model configuration for the LGM simulations.

Polar MM5 uses the Reisner explicit moisture scheme (Reisner et al. 1998) to simulate grid-scale cloud and precipitation processes. This includes three-dimensional prognostic equations for water vapor, cloud water, cloud ice, rain, and snow mixing ratios. Subgrid-scale cloud processes are simulated using the Grell cumulus parameterization (Grell et al. 1994). Shortwave and longwave radiation processes in Polar MM5 are predicted using a modified version of the NCAR Community Climate Model version 2 (CCM2) radiation parameterization (Hack et al. 1993) in conjunction with the predicted cloud water and ice mixing ratios from the Reisner microphysics scheme to determine cloud radiative properties. Turbulent fluxes in the atmosphere and turbulent fluxes between the atmosphere and the surface are parameterized using the 1.5 -order turbulence closure parameterization used in the National Centers for Environmental Prediction Eta Model (Janjic 1994). Polar MM5 includes a sea ice surface type with open water fraction and variable sea ice thickness. Surface fluxes for sea ice grid points are calculated separately for open water and ice fractions, and then averaged before interacting with the overlying atmosphere.

The current model configuration has 29 vertical sigma levels, 7 of which are in the lowest $400 \mathrm{~m}$ of the atmosphere. The lowest sigma level is located nominally at $14 \mathrm{~m}$ above ground level. Guo et al. (2003) conducted Polar MM5 simulations over contemporary Antarctica with a similar vertical resolution near the surface and found that it well captured the evolution of the boundary layer katabatic winds. The model top is set to $13 \mathrm{hPa}$ with a rigid-lid upper boundary condition. The rectangular model domain for the LGM simulations is $170 \times$ 160 horizontal grid points, centered at $52.22^{\circ} \mathrm{N}$, $92.66^{\circ} \mathrm{W}$, with a horizontal polar stereographic projection resolution of $60 \mathrm{~km}$ (Fig. 1).

\section{b. LGM boundary conditions}

The LGM ice sheet elevations are from the University of Maine Ice Sheet Model (UMISM) output (Fastook and Chapman 1989; Fastook and Prentice 1994). The UMISM is a time-dependent finite-element model that solves the mass continuity equation for ice flow and provides the ice surface elevation, isostatically adjusted bedrock elevation, column-integrated ice velocities, and internal temperatures within the ice column at each model grid point. Internal temperatures are calculated at each nodal point using a $1 \mathrm{D}$ vertical temperature profile, with boundary conditions of mean annual temperature at the surface and geothermal heat flux at the bed. The model also calculates creep deformation of the ice and includes a sliding mechanism at locations where the basal tem-

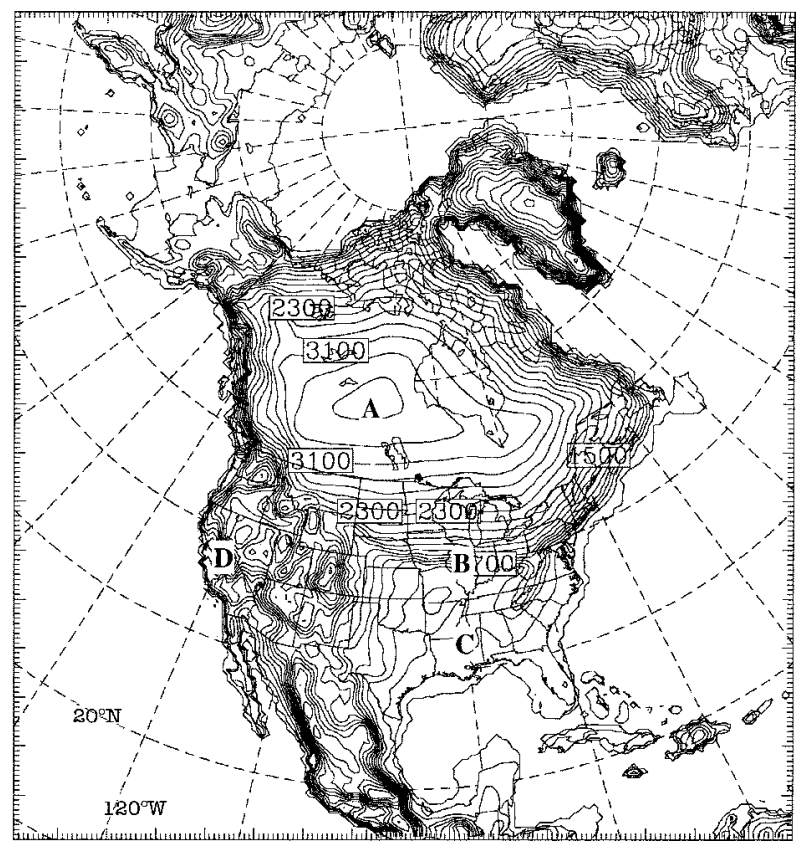

FIG. 1. Polar MM5 LGM domain and terrain elevations contoured every $200 \mathrm{~m}$. Tick marks denote the $60-\mathrm{km}$ grid interval. Latitude and longitude lines have $10^{\circ}$ spacing. Letters (A, B, C, and D) indicate station locations for time series. Note the additional land surface in some coastal locations (e.g., the Bering Strait) outlined by the 0-m (sea level) contour on this topography map. For clarity, this additional land is not shown on later maps.

perature reaches the pressure melting point. The UMISM derives accumulation and ablation rates (e.g., mass balance) using the average annual temperature at the ice surface from a simple climatological model, which is modulated by a temperature proxy obtained from the Greenland Ice Core Project (GRIP) core $\delta^{18} \mathrm{O}$ record (Johnsen et al. 1995). The mass balance scheme, originally derived for Antarctica (Fortuin and Oerlemans 1990; Fastook and Prentice 1994), arrives at an annual mean temperature based on the atmospheric lapse rate and latitudinal temperature gradient. From this temperature, a net accumulation rate is obtained for each model grid point based on the saturation vapor pressure and local surface slope. The net ablation rate is obtained by imposing a latitudinally modified seasonal amplitude onto the annual mean temperature and counting positive-degree days.

The ice sheet data were interpolated to the $60-\mathrm{km}$ Polar MM5 grid using a Cressman weighting scheme (Cressman 1959). Figure 1 shows the contoured LGM terrain elevations in the Polar MM5 domain. The Laurentide Ice Sheet, easily identifiable over North America, exceeds 3500-m elevation (above LGM sea level) just west of Hudson Bay in west-central Canada. The dome elevation is similar to that obtained from geophysically constrained ice sheet model simulations by Tarasov and Peltier (2004). The locations of the Laurentide Ice Sheet margins generally agree with recon- 
TABLE 1. Orbital parameters for the LGM and present day (Berger 1977).

\begin{tabular}{lcc}
\hline \hline & LGM & Present day \\
\hline Eccentricity & 0.01899 & 0.01672 \\
Obliquity & $22.949^{\circ}$ & $23.446^{\circ}$ \\
Longitude of perihelion & $114.42^{\circ}$ & $102.04^{\circ}$ \\
\hline
\end{tabular}

structions from geological data (e.g., Dyke et al. 2002), with the southern margin extending to about $39^{\circ} \mathrm{N}$, although the ice sheet model does not produce the detailed lobelike structures along the southern margin. Elsewhere, a substantial portion of the Fennoscandian Ice Sheet is included in the domain, covering much of the present day United Kingdom, Scandinavia, and Barents Sea; maximum elevations exceed 2400 m over northern Scandinavia and $1700 \mathrm{~m}$ over present day Scotland. In addition, a small ice cap covers the Cherskiy Mountains in eastern Russia $\left(65^{\circ} \mathrm{N}, 145^{\circ} \mathrm{E} ; 2100 \mathrm{~m}\right)$.

In the current ice sheet reconstruction from the glaciological model simulation, Alaska is entirely ice free at the LGM. However, a recent proxy-based reconstruction of LGM glacial extent over present day Alaska predicts that ice extended from the Alexander Archipelago in southwest Alaska, across the Alaska Range, to the western tip of the Alaska Peninsula (Manley and Kaufman 2002). A separate smaller glacier covered the Brooks Range in northern Alaska, while the remainder of the region was ice free at the LGM. To better conform our LGM ice sheet configuration to the proxy estimates of ice extent, Polar MM5 grid points in Alaska were matched qualitatively to the Manley and Kaufman (2002) reconstruction. In the absence of proxy-based estimates of ice sheet thickness in the region, present day terrain elevations (zero ice thickness) were retained at these model grid points.

Orbital forcing in Polar MM5 was set to $21 \mathrm{kyr}$ BP using the equations for eccentricity, declination, and longitude of perihelion from Berger (1977; Table 1). The atmospheric $\mathrm{CO}_{2}$ concentration was set to $180 \mathrm{ppm}$. Sea level was lowered $120 \mathrm{~m}$, commensurate with the LGM global ice sheet volume from glaciological model output but less than recent estimates of sea level lowering ( $\sim 130 \mathrm{~m})$ based on marine evidence (Yokoyama et al. 2000; Peltier 2002). The lowered sea level exposes additional land primarily along the eastern coasts of Central and North America, the Bering Sea, and Bering Strait (Beringia, Fig. 1). Paleovegetation data from reconstructions over Beringia (Edwards et al. 2000), western North America (Thompson and Anderson 2000), and eastern North America (Williams et al. 2000) were matched to the 13 category MM5 vegetation types and qualitatively mapped to the ice-free land grid points in the Polar MM5 domain. Finally, lake level chronologies indicate that the surface areas of paleolakes Lahontan and Bonneville, in the Great Basin of the western United States, were 6-8 times greater at the LGM than at present (Benson et al. 1990; Hostetler et al. 1994). Regional modeling results suggest that Lake Bonneville in particular was sufficiently large for lake-atmosphere interactions to be an important contributor to its hydrologic budget (Hostetler et al. 1994). In the present study, paleolakes Bonneville and Lahontan were implemented in the Polar MM5 domain using a depiction similar to that by Hostetler et al. (1994).

\section{c. PMM5 initial and lateral boundary conditions}

The initial and lateral boundary condition data for the Polar MM5 (PMM5) LGM simulations are from the final year of an 18-yr GCM simulation of the LGM climate using the CCM3, the results of which are presented in detail by Toracinta et al. (2004) and summarized here.

The NCAR CCM3 (Kiehl et al. 1998) is a global spectral atmospheric model with T-42 truncation $\left(2.8^{\circ}\right.$ latitude $\times 2.8^{\circ}$ longitude transform grid), 18 hybrid sigma levels in the vertical, and a $20-$ min. time step. The LGM boundary conditions in the CCM3 simulation were the same as those implemented in PMM5 except that the CCM3 configuration included a modified $\mathrm{CH}_{4}$ concentration (set to $350 \mathrm{ppbv}$ ) and present-day vegetation owing to significant uncertainties in current LGM global vegetation reconstructions. Based on the consensus that the LGM SSTs predicted by Climate: Longrange Investigation, Mapping, and Prediction (CLIMAP 1981) are too warm in the Tropics and too cold at high latitudes, Toracinta et al. (2004) optimized the global LGM SSTs based on available proxy data. The modified LGM SSTs were cooled by $4^{\circ} \mathrm{C}$ uniformly in the Tropics $\left(30^{\circ} \mathrm{N}-30^{\circ} \mathrm{S}\right)$ relative to CLIMAP and the high-latitude sea ice seasonal extent was reduced.

Relevant to the current study, Toracinta et al. (2004) note that the modified LGM SSTs cause significant opposing changes in the hemispheric and regional-scale atmospheric circulation, which are most pronounced in the winter hemisphere. For instance, there is significant weakening of the midlatitude circulation and reduction of 500-hPa eddy kinetic energy (fewer and weaker storm systems) and precipitation along the western coast of North America due to the decreased meridional temperature gradient in the modified SST simulation. In contrast, reduced sea ice extent during boreal winter causes increased regional baroclinicity and enhanced atmospheric circulation in the western North Pacific and the North Atlantic in the vicinity of the Icelandic low. Cooled tropical SSTs also increase the land/ocean temperature contrast, leading to a slightly stronger summer monsoon circulation in the southwestern United States than in the global climate simulation with CLIMAP SSTs.

The 12-hourly CCM3 data, including the three-dimensional temperature, specific humidity, geopotential height, and wind fields as well as surface pressure, snow cover, soil moisture, and soil temperature were interpolated to the Polar MM5 grid using the standard MM5 preprocessing routines. The prescribed monthly mean 
SSTs from the Toracinta et al. (2004) CCM3 simulation were also interpolated to the Polar MM5 grid.

The Polar MM5 LGM simulations were run for a complete annual cycle in a series of monthly runs, each preceded by a 2 -week spinup period. As others have demonstrated, running a long regional climate simulation as a series of shorter, overlapping simulations can minimize model drift and reduce computational cost (Pan et al. 1999; Qian et al. 2003). Polar MM5 output was generated every three hours during May-September to adequately resolve the diurnal cycle in order to quantify warm season ablation of the Laurentide Ice Sheet. Model fields were output every $6 \mathrm{~h}$ during the remainder of the simulated year. Monthly, seasonal, and annual means of several model fields were computed for analysis and comparison with results from the CCM3 LGM simulation over the Polar MM5 domain.

\section{Results}

\section{a. Annual cycle}

In this section we highlight the annual cycle of the LGM climate by presenting maps of monthly mean model fields for January and July along with monthly mean time series from select locations in the Polar MM5 domain.

The mean January 2-m temperature, sea level pressure (SLP), and near-surface (lowest model sigma level) wind distributions are shown in Figs. 2a, 2b, and 2c, respectively. Over the Laurentide Ice Sheet, the coldest 2-m temperatures $\left(<-50^{\circ} \mathrm{C}\right)$ are located along the ice sheet axis of maximum elevation (see Fig. 1), while the coldest $2-\mathrm{m}$ temperatures $\left(<-60^{\circ} \mathrm{C}\right)$ in the model domain are found in central Greenland. The monthly mean $0^{\circ} \mathrm{C}$ isotherm (bold contour) reaches its southernmost position of the year in northern Mexico and the Gulf of Mexico coast. The large temperature gradients along the eastern and western coasts of North America result from the juxtaposition of the Laurentide Ice Sheet margin and relatively warm SSTs.

In response to the cold January temperatures over the elevated, highly reflective Laurentide Ice Sheet, a large "glacial anticyclone" is centered west of Hudson Bay near the peak of the Laurentide Ice Sheet (Fig. 2b). This anticyclone is the dominant feature in the winter SLP field. The January mean Aleutian low $(<988 \mathrm{hPa})$ is located over the Bering Sea while downstream of the Laurentide Ice Sheet a pronounced and equally intense Icelandic low spans the North Atlantic and extends northward over the Greenland Sea. A well-defined anticyclonic katabatic wind circulation is established over the Laurentide Ice Sheet during January (Fig. 2c) with mean near-surface wind speeds in excess of $14 \mathrm{~m} \mathrm{~s}^{-1}$ along the Laurentide Ice Sheet margins. Near-surface wind speeds south of the ice sheet are generally much less but maintain a northerly component from the ice sheet margin to the Gulf of Mexico. Strong near-surface wind flow (12-16 $\mathrm{m} \mathrm{s}^{-1}$ ) also occurs across the North Atlantic in association with the cyclonic circulation around the Icelandic low.

The January mean 500-hPa geopotential height field (Fig. 2d) is highly amplified with a large blocking anticyclone centered near the summit of the Laurentide Ice Sheet and an intense downstream trough and closed low east of Greenland. The 500-hPa height contours and shaded isotachs indicate that the geostrophic flow splits into two distinct branches on the windward side of the Laurentide Ice Sheet. The northern branch of the flow is forced over Beringia and the Canadian Arctic, while the southern branch of the flow traverses the southern portion of the domain. The two branches merge into a single, vigorous transatlantic jet stream with monthly mean $500-\mathrm{hPa}$ level winds in excess of $45 \mathrm{~m} \mathrm{~s}^{-1}$. The 5370- and 5430-m geopotential height contours indicate a closed anticyclonic circulation near the ice sheet summit and a closed cyclonic circulation located south of the ice sheet summit near present day Montana. These closed circulations are not present in the upper levels of the model atmosphere (e.g., $200 \mathrm{hPa}$ ), although the height field aloft remains highly amplified (not shown).

In comparison, by midsummer the atmospheric state over the Laurentide Ice Sheet has changed substantially. For example, Fig. 3 shows the July mean 2-m temperature, sea level pressure, near-surface vector wind, and 500-hPa geopotential height distributions. During July, 2-m air temperatures (Fig. 3a) warm to the annual peak. The July mean $0^{\circ} \mathrm{C}$ isotherm is located along the Laurentide Ice Sheet margins and reaches its farthest northward limit over the North Atlantic and the western Arctic Ocean basin. The mean July SLP field (Fig. 3b) shows the poorly defined glacial anticyclone centered south of Hudson Bay. Both the Aleutian and Icelandic lows are notably weaker, although the latter is still prominent over the North Atlantic. A large transatlantic meridional pressure gradient, between the Icelandic low and high pressure in the central Atlantic, persists during summer and maintains the belt of $10-15 \mathrm{~m} \mathrm{~s}^{-1}$ southwesterly near-surface winds across the basin (Fig. 3c). During July, the katabatic circulation is no longer evident over the Laurentide Ice Sheet in the monthly mean near-surface winds. Rather, relatively strong (10-12 $\mathrm{m} \mathrm{s}^{-1}$ ) low-level flow occurs along the eastern slopes of the ice sheet. The July mean 500-hPa geopotential height field and isotachs (Fig. 3d) indicate a nearly zonal midtropospheric flow traversing the southern margin of the Laurentide Ice Sheet. The broad trough over the North Atlantic, the closed circulation near Greenland, and fast transatlantic flow, though considerably weaker than during winter, are persistent large-scale features during mid summer.

The structure and evolution of the midtropospheric flow has a primary influence on cyclone development, intensity, and track, and therefore the distribution of precipitation. Figure 4 shows the LGM January and July cyclone tracks, which were computed based on an al- 

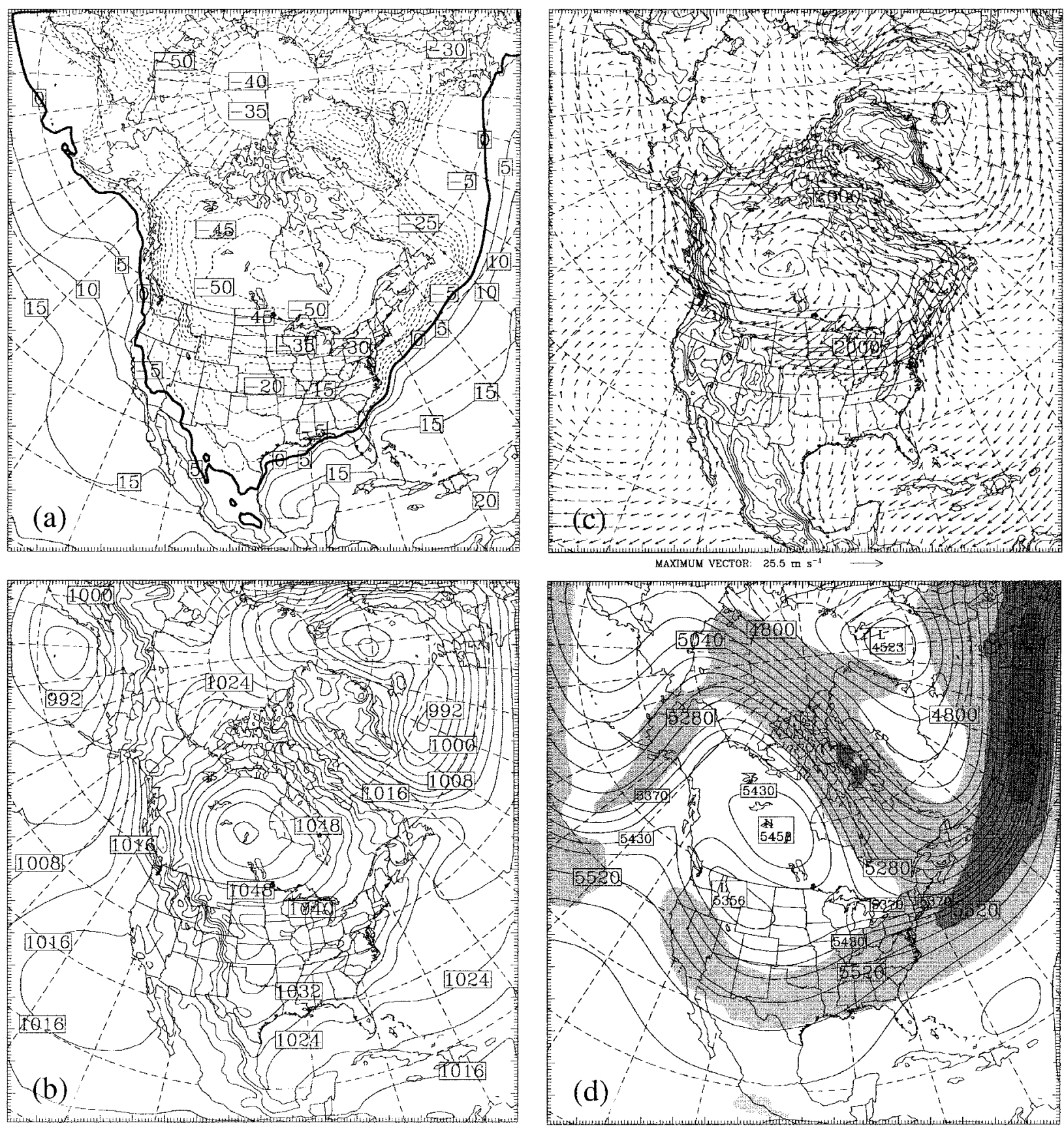

FIG. 2. Polar MM5 LGM Jan monthly mean (a) 2-m air temperature, (b) sea level-pressure, (c) near-surface vector wind and terrain elevation and (d) 500-hPa geopotential height and wind speed. Contour interval is $5^{\circ} \mathrm{C}$ in (a), $4 \mathrm{hPa}$ in (b), $500 \mathrm{~m}$ in (c), and $60 \mathrm{~m}$ in (d). The 5370- and 5430-m geopotential height contours are also shown in (d). Negative values in (a) are dashed and the $0^{\circ} \mathrm{C}$ isotherm is bold. In (d), regions with 500-hPa wind speeds exceeding 15, 30, and $45 \mathrm{~m} \mathrm{~s}^{-1}$ are shaded light, medium, and dark gray, respectively.

gorithm that uses the 6-hourly mean sea level pressure field to define and track surface cyclones in the domain (Serreze 1995; Serreze et al. 1997). The January and July total (convective and grid-scale) precipitation distributions are shown in Fig. 5.

During January (Fig. 4a), surface cyclones occur most frequently at locations along the periphery of the Laurentide Ice Sheet consistent with the split of the jet stream flow around the ice sheet. Cyclones are relatively frequent in the northwestern portion of the domain (e.g., coastal Beringia and Alaska) along the vigorous northern branch of the January split jet stream and across southwestern North America along the southern branch. Accordingly, large precipitation accumulations $(>200 \mathrm{~mm})$ occur in these regions (Fig. 5a). Along the northern branch of the jet stream, cyclones frequently 



FIG. 3. As in Fig. 2 but for Jul.

occur near coastal Greenland and the Fennoscandian Ice Sheet, although the total January precipitation in these high-latitude regions remains relatively small $(<50 \mathrm{~mm})$. In contrast, along the weaker southern branch of the jet stream, both cyclone frequency and total precipitation are maximized in locations from the Gulf of Mexico across the eastern margin of the Laurentide Ice Sheet.

In response to the northward displacement of the midtropospheric jet stream, July cyclone frequencies (Fig. 4b) are relatively high over much of the Laurentide Ice
Sheet, particularly along the southern margin where precipitation totals are also maximized (Fig. 5b). There are attendant decreases in cyclone frequency and precipitation across southern North America.

As the January and July surface and upper-air plots suggest, the katabatic wind circulation over the Laurentide Ice Sheet and the split jet stream have a marked annual cycle. To further illustrate this, we present time series of monthly mean 2-m temperature, sea level pressure, wind speed and direction, and monthly total pre- 



FIG. 4. Polar MM5 LGM cyclone tracks for (a) Jan and (b) Jul. Terrain elevation contour interval is $500 \mathrm{~m}$.

cipitation at select locations in the model domain (see Fig. 1). For instance, Fig. 6 shows the time series at the summit of the Laurentide Ice Sheet. This location is near the center of the katabatic wind circulation and mean wind speeds are generally small (Fig. 6b), particularly during the period when the glacial anticyclone and katabatic wind circulation are firmly established (December-April). Also during this period, the upperlevel split jet stream dominates the large-scale circu-


FIG. 5. Polar MM5 LGM (a) Jan and (b) Jul total (convective and grid-scale) precipitation (thick contours) and terrain elevation. Terrain contour interval is $1000 \mathrm{~m}$. Precipitation contours are 10, 50, 100, 150 , and $200 \mathrm{~mm}$, and every $100 \mathrm{~mm}$ thereafter. Accumulations greater than $200(300) \mathrm{mm}$ are indicated by light (dark) shading.

lation and relatively little precipitation accumulates at the ice sheet summit; less than $28 \%$ of the annual accumulation occurs during the 6-month period from November to April. During the warm season, with the upper-level jet stream positioned over the Laurentide Ice Sheet, transient cyclones track over the ice sheet with increased frequency and precipitation increases mark- 

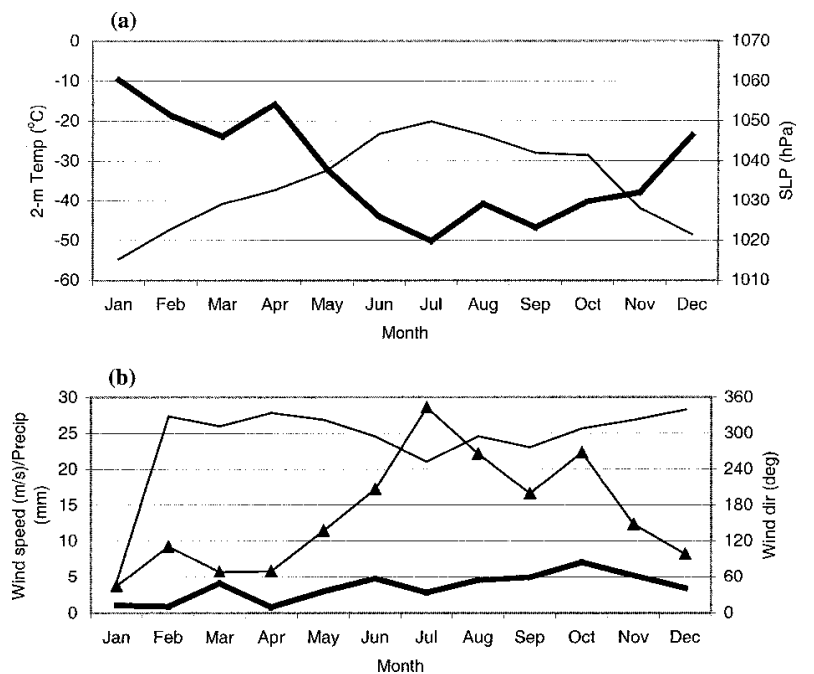

FIG. 6. Time series of (a) monthly mean 2-m temperature (thin) and sea level pressure (bold) and (b) wind speed (bold), vector wind direction (thin), and precipitation (triangles) at location A at the Laurentide Ice Sheet summit (see Fig. 1 and text). Note that the precipitation scale is on the left axis in (b).

edly. In fact, approximately $68 \mathrm{~mm}$ of precipitation (42\% of the annual total) accumulates at the Laurentide Ice Sheet summit during June-August.

Figure 7 shows the monthly mean time series data at a location on the southern margin of the Laurentide Ice Sheet, approximately $250 \mathrm{~km}$ north of the ice sheet terminus (location B in Fig. 1). During the cold season (November-April) katabatic wind regime, monthly mean vector winds are nearly steady from $60^{\circ}$ (downslope of the ice sheet) and precipitation accumulation during the 6-month period accounts for less than 23\% of the annual total accumulation. During summer, monthly mean 2-m air temperatures warm to near freezing. The positioning of the upper-level jet stream over the ice sheet and the attendant increase in transient cyclone frequency result in a marked increase in precipitation from late spring to mid summer; nearly $60 \%$ of the annual precipitation occurs during June-August at this location.

Figure 8 shows the monthly mean time series at a location near the Gulf of Mexico coast (location $\mathrm{C}$ in Fig. 1). Here, the winter months are characterized by high sea level pressure, 2-m air temperatures well below $0^{\circ} \mathrm{C}$, and northerly surface winds. During summer (June-August), the near-surface wind regime is southerly and monthly mean $2-\mathrm{m}$ air temperatures approach $20^{\circ} \mathrm{C}$. The northward migration of the upper-level jet stream results in a decrease in transient cyclone frequency and a seasonal minimum of precipitation (13\% of the annual total) at this location.

The final monthly mean time series (Fig. 9) are from a location in western North America, near present-day Mono Lake, California (location D in Fig. 1). This location is characterized by relatively low amplitude an-
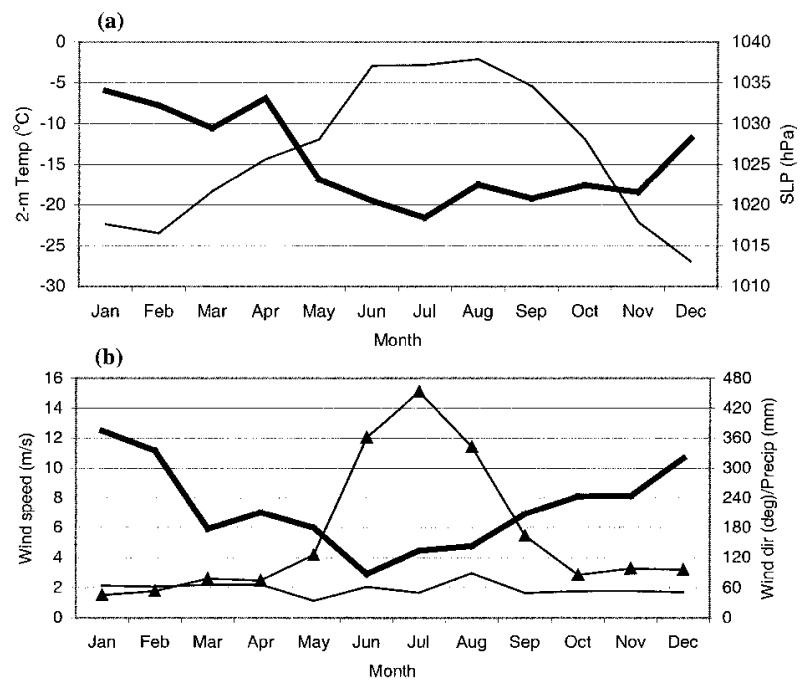

FIG. 7. As in Fig. 6 but at location B on the Laurentide Ice Sheet southern margin (see Fig. 1 and text). Note that the precipitation scale is on the right axis in (b).

nual cycle of the surface variables. The monthly mean near-surface winds are onshore (westerly) from the $\mathrm{Pa}$ cific Ocean through most of the annual cycle, suggesting the prevalence of the eastern Pacific maritime air mass. The southern branch of the upper-level split jet stream influences this region through most of the annual cycle. Thus, monthly precipitation accumulations are consistently large $(>300 \mathrm{~mm})$ except during July-August when the jet stream consolidates and migrates northward over the Laurentide Ice Sheet.

\section{b. Sensitivity of the winter climate to polar physics}

The previous figures demonstrate that the split of the jet stream around the Laurentide Ice Sheet is a distinct


FIG. 8. As in Fig. 6 but at location $\mathrm{C}$ near the Gulf of Mexico coast (see Fig. 1 and text). Note that the precipitation scale is on the right axis in (b). 


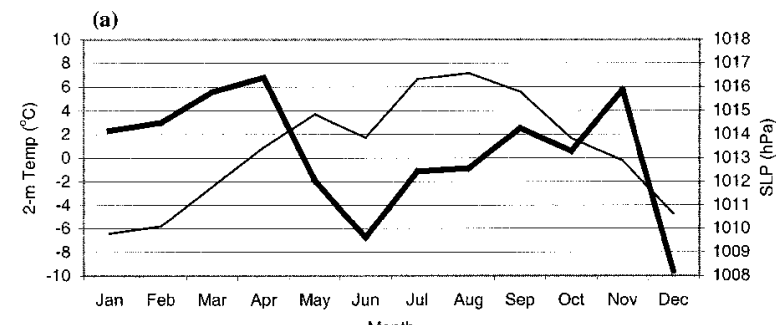

(b)

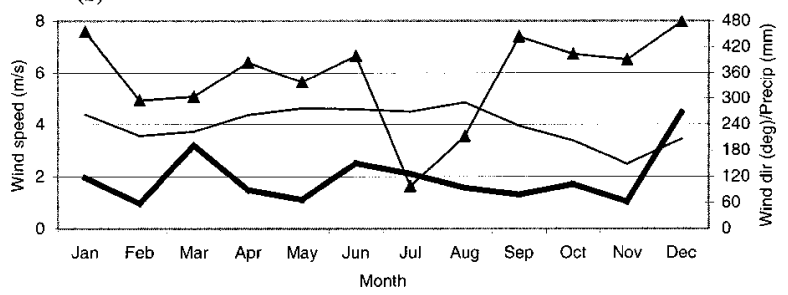

FIG. 9. As in Fig. 6 but at location D (see Fig. 1 and text). Note that the precipitation scale is on the right axis in (b).

feature in the Polar MM5 representation of the LGM winter climate. To better assess the nature of the winter split jet stream, several sensitivity tests were conducted using January as the representative winter month. The first sensitivity test examines the role of the optimized polar physics in the Polar MM5 by repeating the LGM January simulation using the standard release MM5 version 3.4 (MM5 hereafter) without polar physics; all other initial and boundary conditions and physics options (e.g., cloud microphysics and subgrid cumulus parameterization) were unchanged.

The MM5 January mean 2-m air temperature and 2-m air temperature difference (MM5 minus Polar MM5) are shown in Figs. 10a and 10b, respectively. The temperature distribution in Fig. 10a is generally similar to that produced by the Polar MM5 (cf. Fig. 2a) with the $0^{\circ} \mathrm{C}$ isotherm extending to the coast of North America and southward into Mexico. In fact, beyond the ice sheet margins, with the exception of the North Atlantic and Arctic basins, there is essentially no difference between the two model runs (Fig. 10b). The MM5 simulation produces warmer 2-m air temperatures over the ice sheets, consistent with findings by Hines et al. (1997a,b) in simulations over contemporary Antarctica. The positive temperature anomalies over the Laurentide Ice Sheet exceed $18^{\circ} \mathrm{C}$, while large negative anomalies occur in the North Atlantic and Arctic Oceans where sea ice occurs. This is attributed to the treatment of sea ice in Polar MM5, with an open water fraction and variable sea ice thickness allowing greater fluxes of heat from the ocean surface.

The MM5 produces a winter glacial anticyclone (Fig. 11a) over the Laurentide Ice Sheet, centered near the ice sheet summit, as in the Polar MM5 simulation (cf. Fig. 2b). However, consistent with the warmer 2-m air temperatures, MM5 produces a weaker glacial anticyclone over the Laurentide Ice Sheet (Fig. 11b). In addition, the MM5 Icelandic low in the North Atlantic is
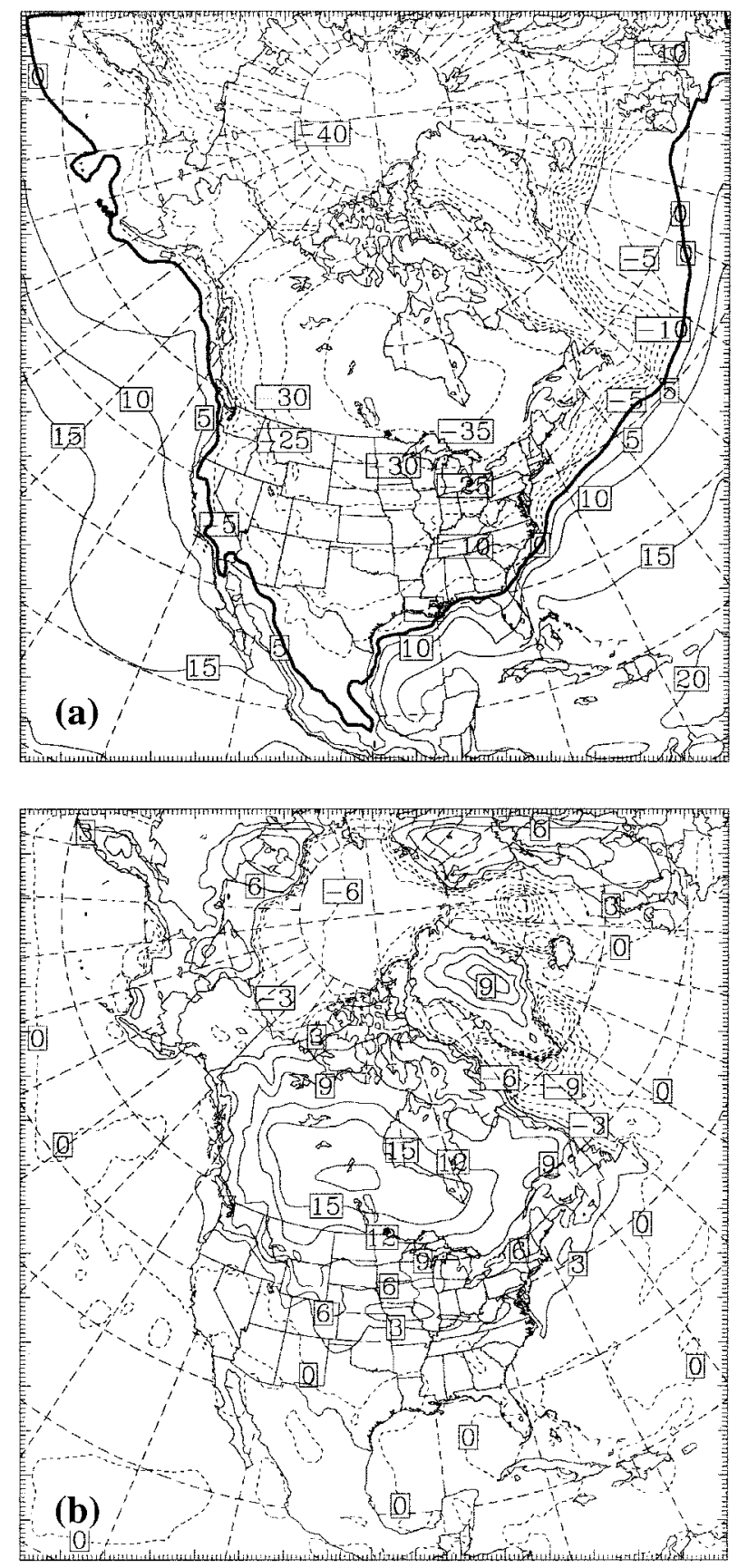

FIG. 10. (a) MM5 (standard release) Jan mean 2-m air temperature and (b) MM5 minus Polar MM5 2-m air temperature difference. Contour interval is $5^{\circ}$ in (a) and $3^{\circ} \mathrm{C}$ in (b). The $0^{\circ} \mathrm{C}$ isotherm is bold in (a). Negative values are dashed.

also weaker [positive mean sea level pressure (MSLP) anomalies] due to the colder temperatures and decreased baroclinicity relative to the Polar MM5 simulation. The warmer temperatures in the MM5 simulation yield a weaker surface inversion and reduced downslope forcing over the Laurentide Ice Sheet such that the katabatic wind circulation is substantially weaker; katabatic wind 

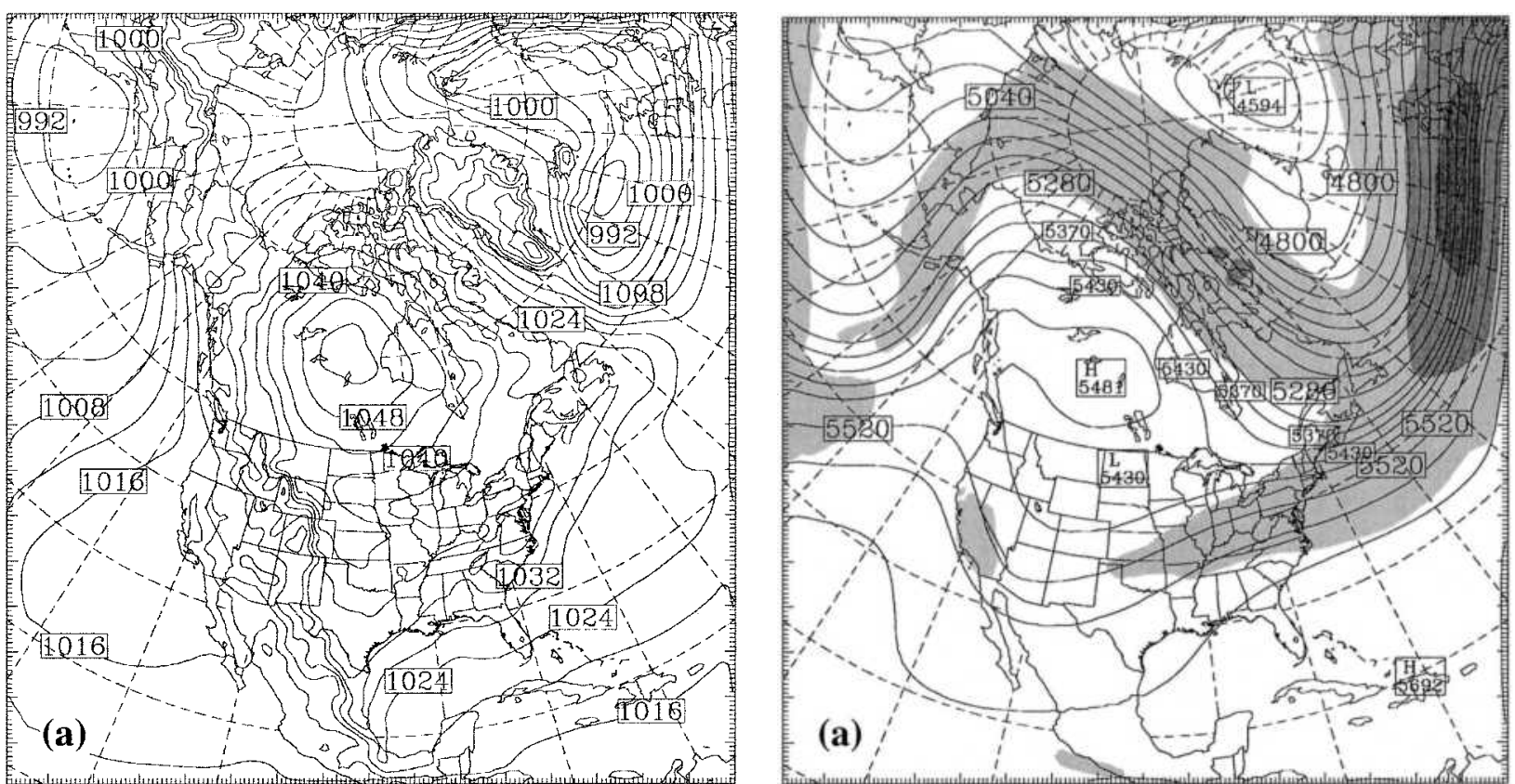

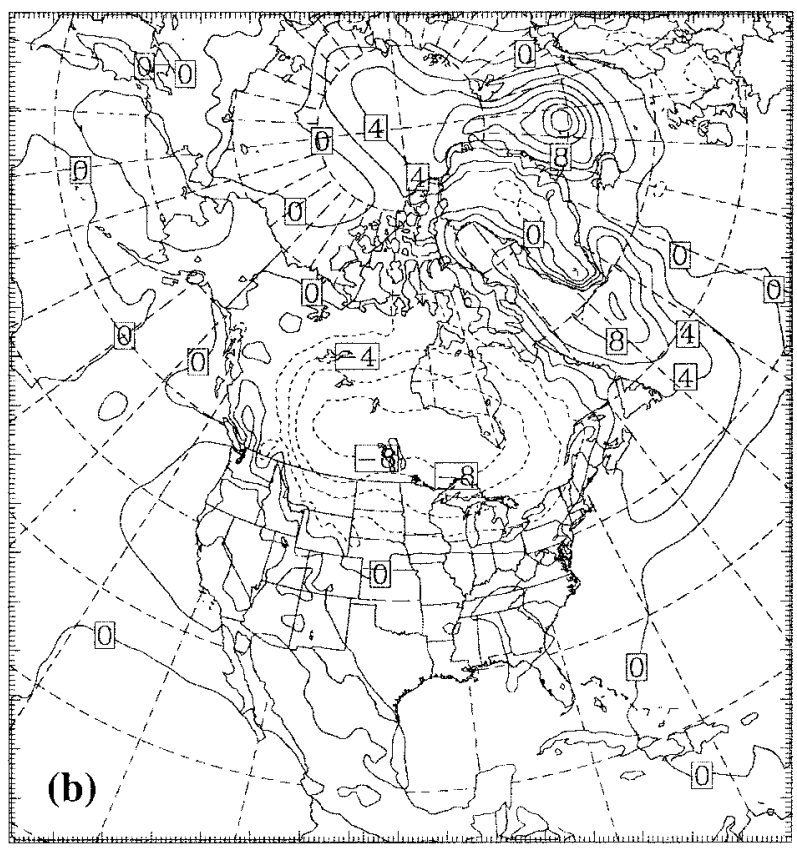

FIG. 11. (a) MM5 (standard release) Jan mean sea level pressure and (b) MM5 minus Polar MM5 sea level pressure difference. Contour interval is 4 in (a) and $2 \mathrm{hPa}$ in (b). Negative values are dashed.

speed magnitudes are roughly half of those in the Polar MM5 run (not shown).

At upper levels, the MM5 simulation without polar physics produces a wintertime split 500-hPa jet stream (Fig. 12a) similar to that in the Polar MM5 run (cf. Fig. 2d). This supports earlier findings that the split jet is largely a result of mechanical forcing by the presence

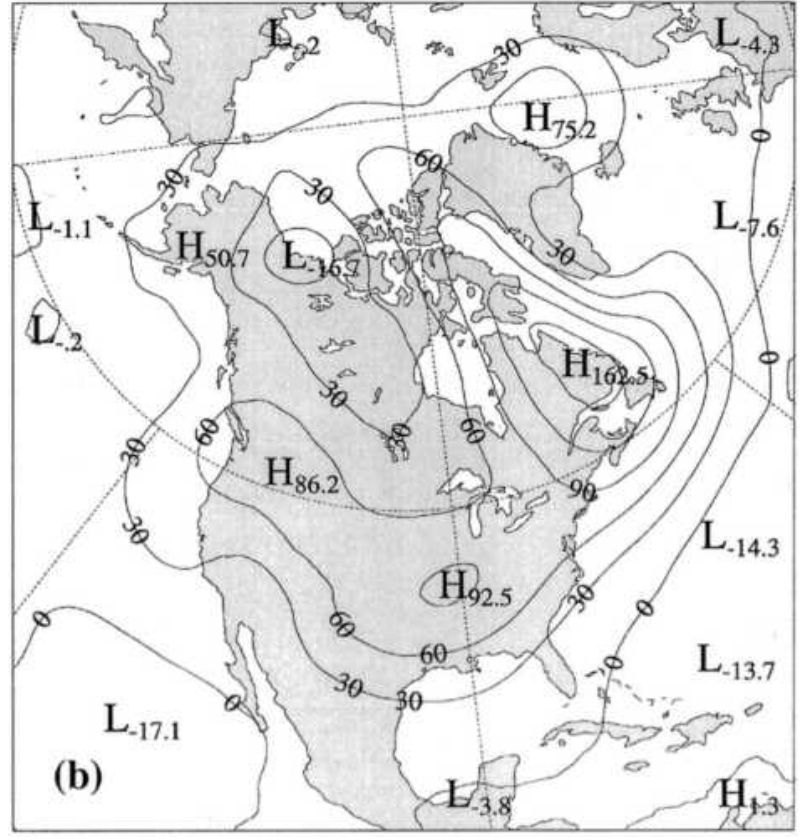

FIG. 12. (a) MM5 (standard release) Jan 500-hPa geopotential height and (b) MM5 minus Polar MM5 500-hPa geopotential height difference. Contour interval is 60 in (a) and $30 \mathrm{~m}$ in (b). The 5370- and 5430-m geopotential height contours are also shown in (a).

of the Laurentide, which acts as an obstacle in the westerly flow (Cook and Held 1988). A quantitative comparison of the 500-hPa flow configurations in the simulations with and without polar physics shows that the blocking anticyclone is somewhat weaker and less pronounced than in the Polar MM5 run. The 500-hPa height anomalies (MM5 minus Polar MM5 Fig. 12b) are pos- 
itive over much of the model domain. The positive height anomalies south of the Laurentide Ice Sheet indicate a weaker trough along the southern branch of the split jet stream. The large positive height anomalies $(>160 \mathrm{~m})$ over Baffin Island and eastern Canada result from a weaker and less amplified trough in the lee of the ice sheet. Consistent with the weaker flow features, the MM5 simulation produces less precipitation along the western portions of the domain, along the southern branch of the split jet stream in southern North America, and in the North Atlantic (not shown).

\section{c. Sensitivity of the winter climate to ice sheet height}

If the Laurentide Ice Sheet acts primarily as an obstacle to the midlatitude westerly flow to mechanically force the wintertime split jet stream, it is reasonable to explore, with the explicit three-dimensional regional model, whether or not a threshold ice sheet height triggers the occurrence of the split jet. To address this question, Polar MM5 was used to conduct a series of winter (January) sensitivity tests with the Laurentide Ice Sheet elevations scaled to various maximum ice sheet heights. The horizontal extent of the Laurentide Ice Sheet was not changed in the sensitivity runs.

For the first sensitivity experiment, the Laurentide Ice Sheet was replaced by a zero thickness ice sheet, similar to previous GCM flat ice sheet experiments (Rind 1987; Felzer et al. 1996; Kageyama and Valdes 2000). Here, however, the terrain elevation at each ice sheet grid point was set to its nonglaciated value and the surface type remained land ice. Figure 13a shows the January mean $500-\mathrm{hPa}$ geopotential height and wind speed distributions. In this case, the dominant midtropospheric flow features are the strong high-latitude jet stream, a closed cyclonic circulation over Greenland, and the associated broad trough over eastern North America. The weak ridge upstream of the flat Laurentide Ice Sheet and pronounced downstream trough account for the large 500$\mathrm{hPa}$ height anomalies (flat minus full) over much of the ice sheet extent (Fig. 13b).

The January mean 2-m air temperature distribution for the flat ice sheet experiment is shown in Fig. 14a. Here, as in the full ice sheet simulation, the mean January $0^{\circ} \mathrm{C}$ isotherm extends to coastal North America (cf. Fig. 2a). However, temperatures south of the Laurentide Ice Sheet margin are warmer than in the full ice sheet control. The January mean $2-\mathrm{m}$ air temperature anomalies (flat minus full) are shown in Fig. 14b. The anomalies were computed by first adjusting the 2 -m temperatures at each Laurentide Ice Sheet grid point by the elevation difference between the full and flat ice sheet topography using the dry adiabatic lapse rate $\left(10^{\circ} \mathrm{C}\right.$ $\mathrm{km}^{-1}$ ). The elevation-adjusted temperature anomalies are negative over most of the Laurentide Ice Sheet extent with the largest negative values occurring over the eastern Canadian Archipelago and Baffin Island. The January mean near-surface vector wind field (Fig. 15) in-
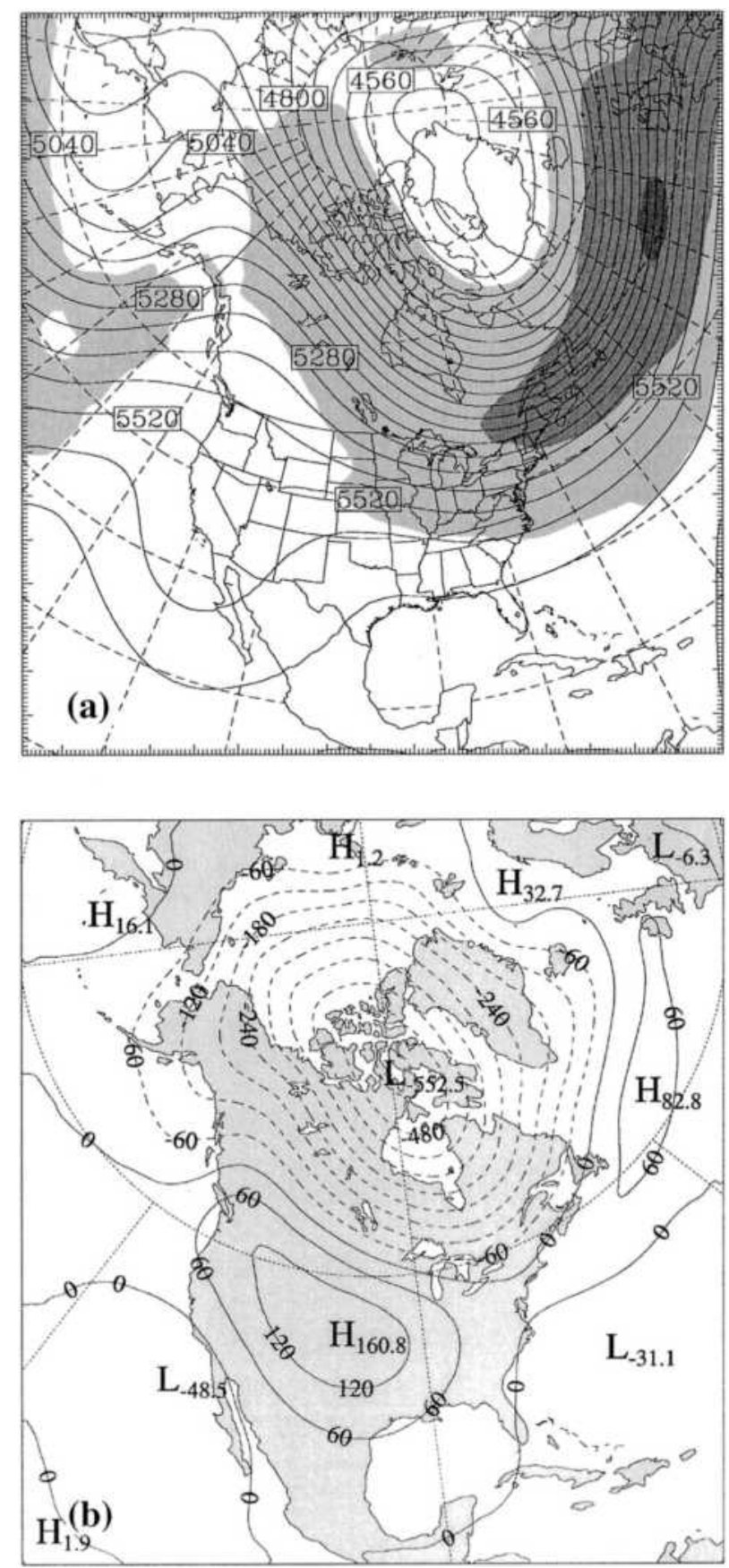

FIG. 13. (a) Polar MM5 Jan 500-hPa geopotential height and wind speed for the flat Laurentide Ice Sheet simulation. (b) Flat minus full Laurentide Ice Sheet 500-hPa height difference. Contour interval is $60 \mathrm{~m}$ in (a) and (b). In (a), regions with 500-hPa wind speeds exceeding 15,30, and $45 \mathrm{~m} \mathrm{~s}^{-1}$ are shaded light, medium, and dark gray, respectively. Negative values in (b) are dashed.

dicates that the large negative anomalies are a result of cold air advection over eastern Canada. In the full ice sheet case, under the influence of strong katabatic flow (Fig. 2c), air parcel trajectories spiral down the slopes of the Laurentide Ice Sheet and the mean January near- 



FIG. 14. (a) Polar MM5 flat Laurentide Ice Sheet Jan 2-m temperature and (b) flat LIS minus full 2-m temperature difference. Contour interval is $5^{\circ} \mathrm{C}$ in (a) and (b). Negative values are dashed.

surface winds are southerly into the Arctic basin. By contrast, the flat ice sheet allows air parcels to traverse unimpeded from the cold Arctic basin over much of eastern Canada.

Similar sensitivity simulations were conducted with the Laurentide Ice Sheet elevations scaled to maximum ice sheet heights of $1000 \mathrm{~m}, 1300 \mathrm{~m}, 1800 \mathrm{~m}, 2100 \mathrm{~m}$, and $2500 \mathrm{~m}$ to determine whether a threshold elevation

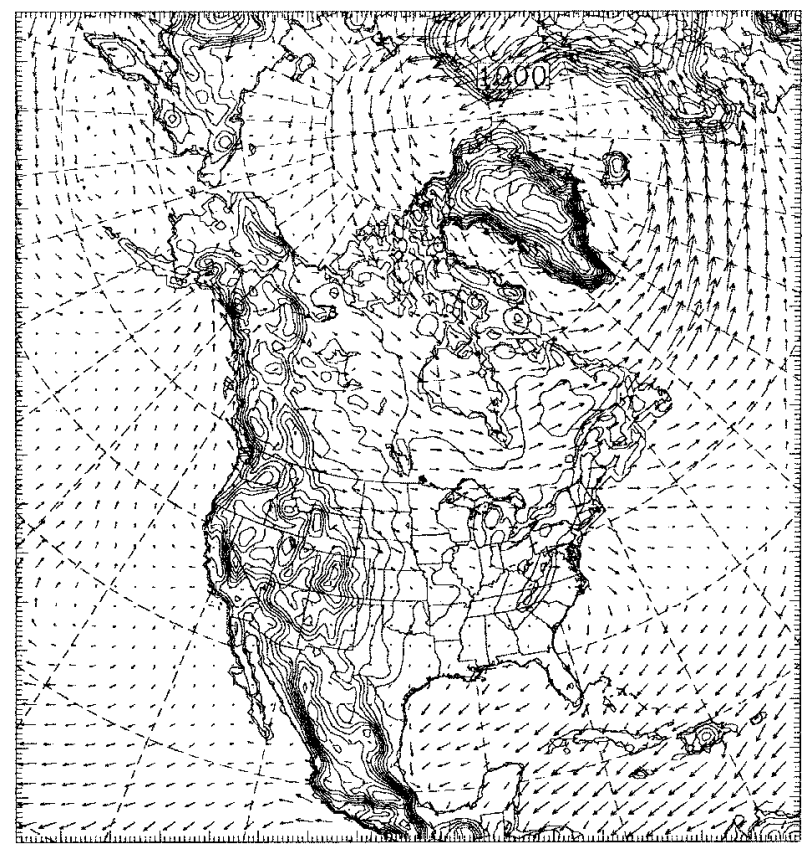

FIg. 15. Polar MM5 flat Laurentide Ice Sheet Jan near-surface vector wind and terrain elevation. Contour interval is $250 \mathrm{~m}$.

exists to trigger onset of the pronounced wintertime split jet. Figure 16 presents the $500-\mathrm{hPa}$ geopotential height anomalies (scaled height minus full) for each of the sensitivity runs at two locations on the Laurentide Ice Sheet: on the ice sheet summit near the center of the anticyclone (open circles) and downstream of the summit over Baffin Island (filled circles). Figure 16 indicates that, as the ice sheet height increases, the negative height anomalies decrease both at the ice sheet summit and downstream of the summit. The former trend is indicative of increased ridging with increased ice sheet height. The latter trend results from an eastward shift and change in amplitude of the downstream trough, some of which may be due in part to the lateral boundary constraint in the northeastern corner of the domain. Although there is some variability, both anomaly trends are approximately linear, indicating that the transition from a weakly split midtropospheric flow over a lowelevation ice sheet to a pronounced split jet stream at

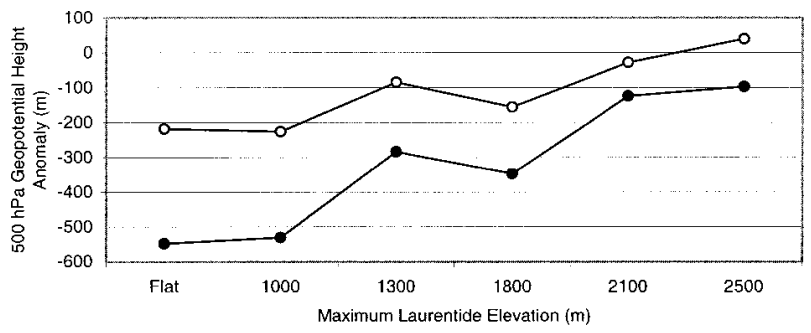

FIG. 16. Polar MM5 Jan mean 500-hPa geopotential height anomalies at locations upstream (open circles) and downstream (filled circles) of the Laurentide Ice Sheet summit (see text). 
full ice sheet height is approximately linear. This corroborates results from one-dimensional model simulations by Cook and Held (1988), who conclude from linear model results that the atmospheric circulation evolved in concert with the growing continental ice sheet and did not change abruptly when the ice sheet reached a critical size.

\section{Discussion}

Early GCM simulations of the Last Glacial Maximum climate show a split upper-level jet stream over the Laurentide Ice Sheet with a strong southern branch of the flow near the southern periphery of the ice sheet and a weaker but distinct branch deflected northward over the Canadian Arctic (e.g., Kutzbach and Wright 1985; Manabe and Broccoli 1985). The winter flow regime from the current Polar MM5 LGM simulation is broadly consistent with these previous GCM results. In the current study, the northern branch of the Polar MM5 winter split jet maintains strong cold air advection in the lee of the Laurentide Ice Sheet while the southern branch is associated with moisture advection from the Gulf of Mexico and Caribbean with enhanced precipitation across much of southern North America. The Polar MM5 solution differs qualitatively from the early GCM results in that Polar MM5 produces a strong northern branch of the split jet whereas the GCM studies clearly show a dominant southern branch. In Polar MM5, the winter midtropospheric westerly jet stream impinges on the Laurentide Ice Sheet farther north than in the GCM studies. This suggests that the characteristics of the trans-Pacific flow, upstream of the ice sheet, determine the relative strengths of the two branches of the split jet stream. In turn, differences in the characteristics of the modeled flow result in part from differences in model resolution, model physics, and the LGM ocean boundary condition.

The Polar MM5 LGM winter solution differs substantially from recently published results from relatively fine spatial resolution GCMs, including those by Toracinta et al. (2004) which were used to provide the initial and lateral boundary conditions for Polar MM5. For instance, Fig. 17 juxtaposes the CCM3 LGM January mean 500-hPa geopotential height field (adapted from Toracinta et al. 2004) with the same field from Polar MM5. The CCM3 solution (Fig. 17a) shows no indication of a split midtropospheric jet stream while Polar MM5 (Fig. 17b), which is constrained to the same CCM3 solution only along the lateral boundaries, produces a very pronounced split jet stream. Other characteristics of the LGM winter climate depicted by Polar MM5, such as the strong glacial anticyclone and katabatic wind flow over the Laurentide Ice Sheet, are also not well represented in the CCM3. Several other Polar MM5 LGM simulations were run using CCM3 initial and lateral boundary data from different model years. The additional Polar MM5 simulations each produced
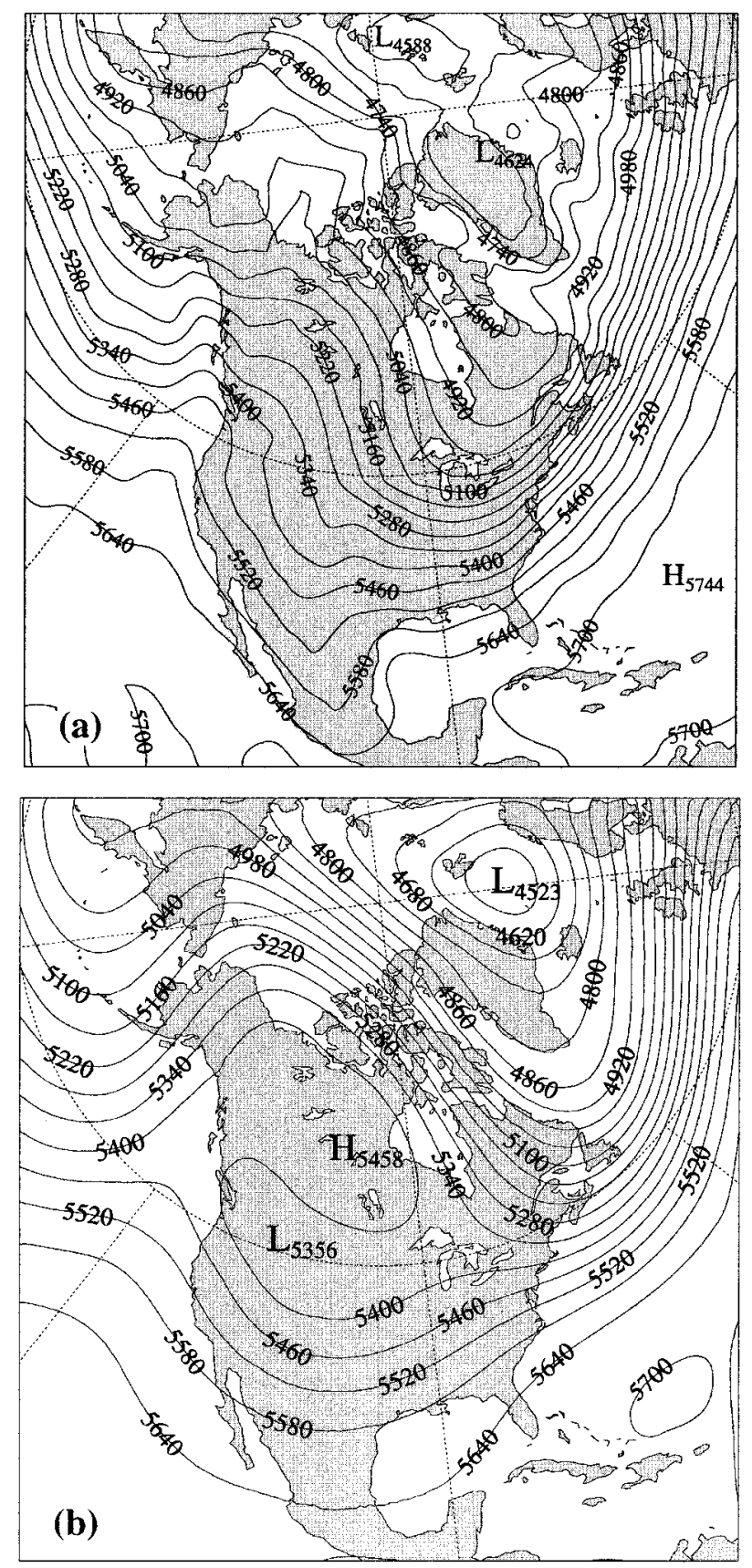

FIG. 17. LGM Jan mean 500-hPa geopotential height from (a) CCM3 (adapted from Toracinta et al. 2004) and (b) Polar MM5. Contour interval is $60 \mathrm{~m}$ in (a) and (b).

very similar qualitative winter circulation features with only small quantitative differences, demonstrating that the regional model solution is robust.

The substantial differences between the global and regional model solutions are attributable to several factors. First, model physics contribute to the differences, as the regional model simulations with and without polar physics demonstrate. The optimized physics in Polar MM5 (which are not present in CCM3) yield enhanced 

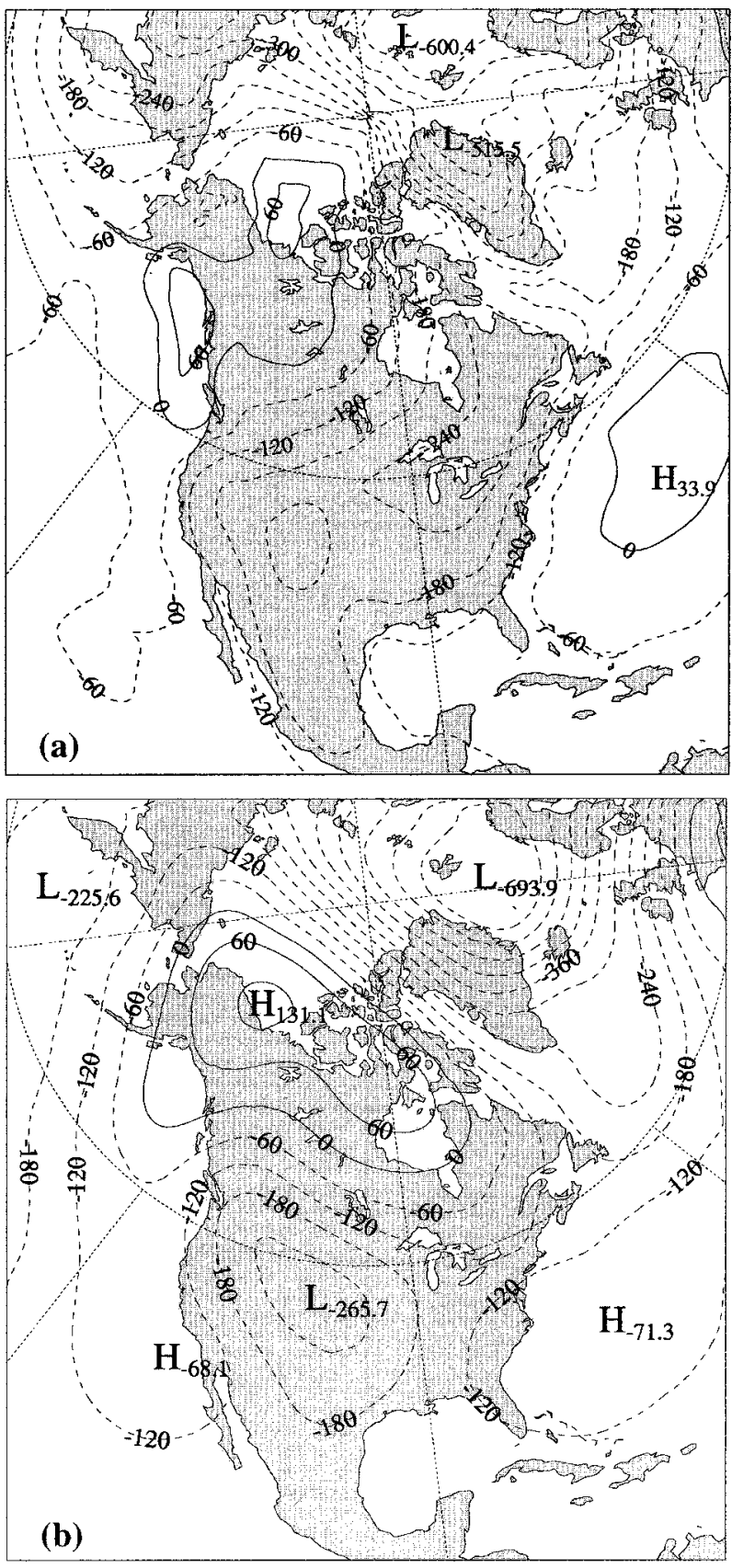

FIG. 18. Jan 500-hPa geopotential height anomalies (LGM minus present) from (a) CCM3 and (b) Polar MM5. Contour interval is 60 $\mathrm{m}$ in (a) and (b). Negative values are dashed.

winter circulation features compared to the simulation without polar physics. Second, model resolution contributes to the different winter solutions in Polar MM5 and CCM3. For instance, the 500-hPa geopotential height anomalies (LGM minus present) from CCM3 and Polar MM5 simulations are shown in Figs. 18a and 18b, respectively. CCM3 produces modest $(60 \mathrm{~m})$ positive height anomalies upstream of the Laurentide Ice Sheet and over the central Atlantic Ocean with larger negative height anomalies from eastern North America across the North Atlantic. In comparison, the 500-hPa geopotential height anomaly pattern from Polar MM5 (Fig. 18b) is more highly amplified. Similarly, Rind (1988) finds that a GCM simulation of the ice age climate at "fine" resolution $\left(4^{\circ} \times 5^{\circ}\right)$ produces a more highly amplified circulation pattern in the Northern Hemisphere winter than the same GCM at coarser $\left(8^{\circ} \times 10^{\circ}\right)$ resolution. The extent and magnitude of the positive height anomalies over North America in Polar MM5 indicate that the model atmosphere responds more strongly to the presence of the Laurentide Ice Sheet than the coarser resolution CCM3.

Although the CCM3 response to the ice sheet forcing is less amplified than in the regional model, the global model domain is horizontally unbounded and disturbances are allowed to propagate freely downstream. The response of the Polar MM5 atmosphere to the presence of the Laurentide Ice Sheet is constrained at the lateral boundaries. Hence, it is valid to question whether the domain is sufficiently large to capture the primary effects of the ice sheet forcing. Evidence that the Polar MM5 domain is sufficiently large can be gleaned from results by Cook and Held (1988), who used a linear model driven by output from an early GCM simulation of the LGM with a winter jet stream split around the Laurentide Ice Sheet (Broccoli and Manabe 1987). Cook and Held (1998) find that the largest atmospheric response to ice sheet orographic forcing occurs locally over North America and the North Atlantic. The high amplitude anomalies in this region are contained within the Polar MM5 domain. In addition, the Polar MM5 January LGM simulation was run on a smaller domain $(140 \times 130$ horizontal grid points, $60-\mathrm{km}$ spacing $)$ with no substantial differences in the representation of the split jet stream. Thus, the Polar MM5 domain size is sufficiently large to capture the first-order effects of the Laurentide Ice Sheet.

\section{Comparison of model output and proxy data}

Annual mean surface temperature estimates at the LGM are available from a number of proxy sources within the Polar MM5 domain. Table 2 lists a sample of proxy-based estimates of surface temperature cooling at the LGM at sites mostly in the western United States. Also listed are the predicted annual mean 2-m temperature changes (LGM minus present) from Polar MM5 and CCM3 simulations. Both models are in close agreement with temperature estimates from Greenland borehole data showing $21^{\circ} \mathrm{C}$ cooling in central Greenland at the LGM. Elsewhere, in some locales the Polar MM5 solution is in closer agreement than CCM3 with proxy temperature estimates [e.g., those from Stute et al. (1995) and Thompson et al. (1993)], while at other sites the models are in similar disagreement with the proxy data. Overall, for this small sample of data points, Polar MM5 shows closer agreement with the proxy temper- 
TABLe 2. Annual mean 2-m temperature difference [LGM minus present (PD), $\left.{ }^{\circ} \mathrm{C}\right]$ from proxy data estimates and Polar MM5 (CCM3) model output. Differences are negative and error bars are as listed in the cited study.

\begin{tabular}{|c|c|c|c|c|}
\hline Source & Proxy method & Location & $\begin{array}{l}\text { Temperature } \\
\text { reduction, proxy }\end{array}$ & $\begin{array}{c}\text { Polar MM5 (CCM3) } \\
\text { minus PD }\end{array}$ \\
\hline Cuffy et al. (1995) & Borehole & $72.6^{\circ} \mathrm{N}, 38.5^{\circ} \mathrm{W}$ & 21 & $21.1(21.1)$ \\
\hline Dahl-Jensen et al. (1998) & Borehole & $72.6^{\circ} \mathrm{N}, 37.6^{\circ} \mathrm{W}$ & $21 \pm 1.0$ & $21.1(20.9)$ \\
\hline Lemons et al. (1996) & Lake sediment/model & $41.0^{\circ} \mathrm{N}, 112.2^{\circ} \mathrm{W}$ & 13 & $6.7(7.4)$ \\
\hline Thompson et al. (1993) & Midden & $34.6^{\circ} \mathrm{N}, 117.6^{\circ} \mathrm{W}$ & 6 or more & $4.8(5.3)$ \\
\hline Li et al. (1996) & Midden & $36.8^{\circ} \mathrm{N}, 116.1^{\circ} \mathrm{W}$ & $6-7$ & $4.9(6.9)$ \\
\hline \multirow[t]{2}{*}{ Farrera et al. (1999) } & Noble gases & $32.0^{\circ} \mathrm{N}, 81.5^{\circ} \mathrm{W}$ & $4 \pm 0.5$ & $5.0(7.9)$ \\
\hline & Noble gases & $29.0^{\circ} \mathrm{N}, 98.8^{\circ} \mathrm{W}$ & $5 \pm 0.7$ & $8.3(8.6)$ \\
\hline Stute et al. (1992) & Noble gases & $28.75^{\circ} \mathrm{N}, 98.5^{\circ} \mathrm{W}$ & $5.2 \pm 0.7$ & $8.1(8.4)$ \\
\hline Stute et al. (1995) & Noble gases & $36.6^{\circ} \mathrm{N}, 108.1^{\circ} \mathrm{W}$ & $5.4 \pm 0.7$ & $6.4(7.7)$ \\
\hline Thompson et al. (1993) & Noble gases & $32.5^{\circ} \mathrm{N}, 106.6^{\circ} \mathrm{W}$ & $5-7$ & $7.0(7.9)$ \\
\hline \multirow[t]{2}{*}{ Farrera et al. (1999) } & Pollen & $22.0^{\circ} \mathrm{N}, 100.5^{\circ} \mathrm{W}$ & $1.5-3$ & $7.2(6.7)$ \\
\hline & Pollen & $16.9^{\circ} \mathrm{N}, 89.9^{\circ} \mathrm{W}$ & $6.5-8$ & $6.2(6.4)$ \\
\hline \multirow[t]{3}{*}{ Thompson et al. (1993) } & Pollen & $47.8^{\circ} \mathrm{N}, 122.9^{\circ} \mathrm{W}$ & 6 & $5.8(6.5)$ \\
\hline & Pollen & $45.8^{\circ} \mathrm{N}, 122.5^{\circ} \mathrm{W}$ & $6-7$ & $3.7(4.5)$ \\
\hline & Pollen & $38.9^{\circ} \mathrm{N}, 122.6^{\circ} \mathrm{W}$ & $7-8$ & $4.7(3.9)$ \\
\hline
\end{tabular}

ature estimate, but the differences with the CCM3 solution are generally modest.

Precipitation estimates for the LGM are commonly determined from lake level data. Lake level status for a number of closed basins in the western United States indicates wetter conditions at the LGM compared to the present (e.g., Street-Perrott et al. 1989). Both CCM3 and Polar MM5 generally capture the increased precipitation at the LGM across the western United States, although there are notable differences that are attributable to the different flow configurations in the two



FIG. 19. Polar MM5 minus CCM3 LGM Jan total (convective plus grid-scale) precipitation difference. Contours are at 25, 50, 75, $100 \mathrm{~mm}$ and every $100 \mathrm{~mm}$ thereafter. Negative values are dashed. models. For instance, Fig. 19 shows the Polar MM5 minus CCM3 January precipitation anomalies; here the Polar MM5 data have been spatially averaged to match the CCM3 grid. Under the influence of the wintertime split jet stream, Polar MM5 predicts enhanced precipitation relative to CCM3 across much of western North America, particularly in the western United States. While both models broadly agree with proxy data in this region, there is considerable regional variability, especially in the finer resolution Polar MM5. For instance, based on sediment yield rates in the Bonneville Basin of northern Utah, Lemons et al. (1996) predict that annual precipitation was as much as $33 \%$ greater during the LGM than today. By comparison, results from CCM3 and Polar MM5 show only minor increases of $2.9 \%$ and $8.1 \%$, respectively, in this region. Elsewhere, proxy records suggest that annual precipitation in northern California was 300\% greater at the LGM (Thompson et al. 1993). Here again, both models predict minor increases in annual precipitation in this region at the LGM: $6.7 \%$ for CCM3 and $11.5 \%$ for Polar MM5. Although the Polar MM5 shows considerably more regional variability in the distribution of precipitation, the $60-\mathrm{km}$ spatial resolution is not sufficient to accurately represent complex relief such as the Rocky Mountains and hence may not be accurately capturing the detailed distribution of LGM precipitation.

Over northwestern North America, estimates of LGM climate are available from a few proxy sources including pollen and the distribution of loess. Muhs and Zárate (2001) note that, although loess source areas in Alaska are not well established nor is the amount of loess deposition that took place at the LGM, the dust source model of Mahowald et al. (1999) suggests that interior Alaska was an important loess source at this time. This is consistent with the pollen record of cold, dry conditions and a sparsely vegetated landscape in central and western Alaska (Ager and Brubaker 1985; Ager 
2003). Briner and Kaufman (2000) infer that moist air masses penetrated infrequently into southwestern Alaska (eastern Beringia) during the late Wisconsin period (LGM). They state that lowered sea level at the LGM exposed a vast continental shelf that transformed the climate in southwestern Alaska from maritime to continental. This inference is supported by the magnitude of equilibrium line altitude (ELA) lowering, which suggests that the region was unusually dry. Both the regional Polar MM5 and global CCM3 predict drier conditions in western and central Alaska at the LGM in general agreement with proxy data. As in the southwestern United States Polar MM5 produces substantial regional variability not seen in the global model. Both models predict increased precipitation at the LGM along coastal southern Alaska, although the magnitudes are notably greater in Polar MM5 due in part to the influence of the winter split jet stream and a more accurate representation of the mountainous terrain in this region.

Muhs et al. (2003) suggest that full-glacial loess in western Alaska is largely glaciofluvial in origin and that probable source regions imply a prevailing northeasterly wind during the LGM. This is in contrast to winds simulated in earlier GCM simulations of the LGM climate (e.g., Kutzbach et al. 1993) that show prevailing southwesterly winds over Alaska. The Polar MM5 LGM run predicts easterly winds over Alaska through most of the annual cycle, in general agreement with proxy observations.

The enhanced precipitation along the southern coast of Alaska in the Polar MM5 LGM simulation is also attributable to the influence of the split jet stream, the northern branch of which steers low pressure systems across Beringia and into the Arctic. The northern branch of the jet stream in Polar MM5 also results in enhanced precipitation in the Canadian Arctic, particularly over the Queen Elizabeth Islands and northwestern Greenland. This is in contrast to results from the CCM3 simulation that predicts arid conditions in this region at the LGM.

Although proxy evidence is sparse in the Canadian High Arctic, recent studies challenge the notion of regional aridity at the LGM and appear more consistent with results from Polar MM5. For instance, geomorphic and stratigraphic evidence along the Nares Strait (between Ellesmere Island and Greenland) indicate glacial advance and coalescent Greenland and Ellesmere Island ice during the late Wisconsinan period (England 1999). Dyke (1999) also points to evidence from Devon Island suggesting that the region was inundated with ice at the LGM. In the Arctic basin, Polyak et al. (2001) present submarine topographic evidence for extensive thick ice shelves during Pleistocene glaciations. Flow directions inferred from the orientation of submarine glaciogenic features suggest that glaciation of the Canadian High Arctic was one source for the Arctic Ocean ice shelves. Although the dating of the glaciogenic features on the seafloor is not well constrained, Polyak et al. (2001) speculate that grounded ice may have existed in the western Arctic Ocean at the LGM.

\section{Conclusions}

Polar MM5 simulations of the Last Glacial Maximum climate, using a high spatial resolution $(60 \mathrm{~km})$ domain centered over North America and driven by output from an NCAR CCM3 LGM simulation, produce distinct characteristics of the atmospheric circulation not seen in recent GCM simulations of the LGM. Foremost among these is the pronounced split of the Northern Hemisphere jet stream around the Laurentide Ice Sheet during the cold season (November-April). Sensitivity experiments indicate that the winter split jet stream is primarily due to mechanical forcing by the Laurentide Ice Sheet, which acts as an obstacle in the midlatitude westerly flow. It appears that the characteristics of the atmospheric flow upstream of the Laurentide Ice Sheet influence the structure of the midlatitude jet stream and could account for differences in the regional and global model depictions of the jet configuration. While the primary influence of the Laurentide Ice Sheet on the atmospheric circulation is proximate to the ice sheet (i.e., away from the Polar MM5 lateral boundaries), future experiments will consider the downstream impact of the ice sheet within a larger (possibly hemispheric) Polar MM5 domain.

The atmospheric flow configuration from Polar MM5 has a first-order impact on the regional distributions of temperature and precipitation in the model domain. Polar MM5 produces a mean annual temperature distribution in general agreement with available proxy data, and simulated temperature anomalies differ only slightly from the CCM3 solution. With regard to precipitation, the Polar MM5 solution is in qualitative agreement with CCM3 and proxy data that the southwestern United States was wetter at the LGM than today. There are important quantitative differences between Polar MM5 and the proxy records that may be due to model resolution. Compared with CCM3, Polar MM5 produces substantially greater regional variability in the precipitation distribution over western North America. However, the 60-km horizontal resolution in Polar MM5 may not sufficiently represent the mountainous terrain of the region in order to capture accurately the precipitation distribution.

At high latitudes, the Polar MM5 LGM simulation is consistent with available proxy data showing generally dry conditions in the Alaskan interior under an easterly low-level wind regime. Substantial differences between Polar MM5 and CCM3 are noted in the Canadian High Arctic, where the regional model produces enhanced precipitation in association with the northern branch of the split jet stream. This is also in contrast to previous GCM simulations that predict aridity in the Arctic at the LGM. Although proxy data are sparse in this region, the enhanced precipitation simulated by Polar MM5 is 
broadly consistent with paleoreconstructions of extensive glaciation over the Queen Elizabeth Islands and proposed ice shelves in the Arctic during the LGM. Both at high and middle latitudes, the results from Polar MM5 may help resolve some long-standing discrepancies between proxy data and previous simulations of the LGM climate.

Acknowledgments. This research was funded by National Science Foundation Grant OPP-9905381 to David H. Bromwich. We would like to thank Lev Tarasov and an anonymous reviewer for their constructive comments. We greatly appreciate discussions and comments from Mark Anderson, John England, and Leonid Polyak. Our thanks also to Rahul George and Ragharendra Mupparthy for data-processing assistance.

\section{REFERENCES}

Ager, T. A., 2003: Late Quaternary vegetation and climate history of the central Bering land bridge from St. Michael Island, western Alaska. Quat. Res., 60, 19-32.

—_, and L. Brubaker, 1985: Quaternary palynology and vegetational history of Alaska. Pollen Records of Late-Quaternary North American Sediments, V. M. Bryant Jr. and R. G. Holloway, Eds., American Association of Stratigraphic Palynologists Foundation, 353-383.

Benson, L. V., D. R. Currey, R. I. Dorn, K. R. Lajoie, C. G. Oviatt, S. W. Robinson, G. I. Smith, and S. Stine, 1990: Chronology of expansion and contraction of four Great Basin lake systems during the past 35,000 years. Palaeogeogr., Palaeoclimatol., Palaeoecol., 78, 241-286.

Berger, A., 1977: Long-term variations of the earth's orbital elements. Celest. Mech., 15, 53-74.

Briner, J. P., and D. S. Kaufman, 2000: Late Pleistocene glaciation of the southwestern Ahklun Mountains, Alaska. Quat. Res., 53, $13-22$.

Broccoli, A. J., and S. Manabe, 1987: The influence of continental ice, atmospheric $\mathrm{CO}_{2}$, and land albedo on the climate of the last glacial maximum. Climate Dyn., 1, 87-99.

Bromwich, D. H., J. J. Cassano, T. Klein, G. Heinemann, K. M. Hines, K. Steffen, and J. E. Box, 2001: Mesoscale modeling of katabatic winds over Greenland with the Polar MM5. Mon. Wea. Rev., 129, 2290-2309.

— - A. J. Monaghan, J. J. Powers, J. J. Cassano, H. Wei, Y. Kuo, and A. Pellegrini, 2003: Antarctic Mesoscale Prediction System (AMPS): A case study from the 2000/2001 field season. Mon. Wea. Rev., 131, 412-434.

Cassano, J. J., J. E. Box, D. H. Bromwich, L. Li, and K. Steffen, 2001: Evaluation of Polar MM5 simulations of Greenland's atmospheric circulation. J. Geophys. Res., 106, 33 867-33 890.

CLIMAP, 1981: Seasonal Reconstruction of the Earth's Surface at the Last Glacial Maximum. Map and Chart Series, Vol. 36, Geological Society of America, 18 pp.

Cook, K. H., and I. M. Held, 1988: Stationary waves of the ice age climate. J. Climate, 1, 807-819.

Cressman, G. P., 1959: An operational objective analysis system. Mon. Wea. Rev., 87, 367-374.

Cuffey, K. M., G. D. Clow, R. B. Alley, M. Stuiver, E. D. Waddington, and R. W. Saltus, 1995: Large Arctic temperature change at the Wisconsin-Holocene glacial transition. Science, 270, 455-458.

Dahl-Jensen, D., K. Mosegaard, N. Gundestrup, G. D. Clow, S. J. Johnsen, A. W. Hansen, and N. Balling, 1998: Past temperatures directly from the Greenland Ice Sheet. Science, 282, 268-271.

Dong, B., and P. J. Valdes, 2000: Climates at the Last Glacial Max- imum: Influence of model horizontal resolution. J. Climate, 13, $1554-1573$.

Dudhia, J., 1993: A nonhydrostatic version of the Penn State-NCAR Mesoscale Model: Validation tests and simulation of an Atlantic cyclone and cold front. Mon. Wea. Rev., 121, 1493-1513.

Dyke, A. S., 1999: Last Glacial Maximum and deglaciation of Devon Island, Arctic Canada: Support for an Innuitian ice sheet. Quat. Sci. Rev., 18, 393-420.

— , J. T. Andrews, P. U. Clark, J. H. England, G. H. Miller, J. Shaw, and J. J. Veillette, 2002: The Laurentide and Innuitian ice sheets during the Last Glacial Maximum. Quat. Sci. Rev., 21, 9-31.

Edwards, R. L., and Coauthors, 2000: Pollen-based biomes for Beringia 18,000, 6000 and $0{ }^{14} \mathrm{C}$ yr BP. J. Biogeogr., 27, 521-554.

England, J., 1999: Coalescent Greenland and Innuitian ice during the Last Glacial Maximum: Revising the Quaternary of the Canadian High Arctic. Quat. Sci. Rev., 18, 421-456.

Farrera, I., and Coauthors, 1999: Tropical climates at the Last Glacial Maximum: A new synthesis of terrestrial palaeoclimate data. I. Vegetation, lake-levels, and geochemistry. Climate Dyn., 15, $823-856$

Fastook, J. L., and J. Chapman, 1989: A map plane finite-element model: Three modeling experiments. J. Glaciol., 35, 48-52.

_- and M. Prentice, 1994: A finite-element model of Antarctica: Sensitivity test for meteorological mass balance relationship. $J$. Glaciol., 40, 167-175.

Felzer, B., R. J. Oglesby, T. I. Webb, and D. E. Hyman, 1996: Sensitivity of a general circulation model to changes in Northern Hemisphere ice sheets. J. Geophys. Res., 101, 19 077-19 092.

Fortuin, I. P. F., and J. Oerlemans, 1990: Parameterization of the annual surface temperature and mass balance of Antarctica. Ann. Glaciol., 14, 78-84.

Giorgi, F., M. R. Marinucci, and G. Visconti, 1990: Use of a limitedarea model nested in a general circulation model for regional climate simulation over Europe. J. Geophys. Res., 95, $18413-$ 18431.

Grell, G. A., J. Dudhia, and D. R. Stauffer, 1994: A description of the fifth-generation Penn State-NCAR Mesoscale Model (MM5). NCAR Tech. Note NCAR/TN-398+STR, 122 pp.

Guo, Z., D. H. Bromwich, and J. J. Cassano, 2003: Evaluation of Polar MM5 simulations of Antarctic atmospheric circulation. Mon. Wea. Rev., 131, 384-411.

Hack, J. J., B. A. Boville, B. P. Briegleb, J. T. Kiehl, P. J. Rasch, and D. L. Williamson, 1993: Description of the NCAR community climate model (CCM2). NCAR Tech. Note NCAR/TN$382+$ STR, 108 pp.

Hall, N. M., P. J. Valdes, and B. Dong, 1996: The maintenance of the last great ice sheets: A UGAMP GCM study. J. Climate, 9, 1004-1019.

Hines, K. M., D. H. Bromwich, and R. I. Cullather, 1997a: Evaluating moist physics for Antarctic mesoscale simulations. Ann. Glaciol., 25, 282-286.

- - - , and Z. Liu, 1997b: Combined global climate model and mesoscale model simulations of Antarctic climate. J. Geophys. Res., 102, $13747-13760$.

Hostetler, S. W., F. Giorgi, G. T. Bates, and P. J. Bartlein, 1994: Lakeatmosphere feedbacks associated with paleolakes Bonneville and Lahontan. Science, 263, 665-668.

Janjić, Z. I., 1994: The step-mountain eta coordinate model: Further developments of the convection, viscous sublayer, and turbulence closure schemes. Mon. Wea. Rev., 122, 927-945.

Ji, Y., and A. D. Vernekar, 1997: Simulation of the Asian summer monsoons of 1987 and 1988 with a regional model nested in a global GCM. J. Climate, 10, 1965-1979.

Johnsen, S. J., D. Dahl-Jensen, W. Dansgaard, and N. Gundestrup, 1995: Greenland paleotemperatures derived from GRIP bore hole temperature and ice core isotope profiles. Tellus, 47, 624629.

Kageyama, M., and P. J. Valdes, 2000: Impact of the North American ice-sheet orography on the Last Glacial Maximum eddies and snowfall. Geophys. Res. Lett., 27, 1515-1518. 
Kiehl, J. T., J. J. Hack, G. B. Bonan, B. A. Boville, D. L. Williamson, and P. J. Rasch, 1998: The National Center for Atmospheric Research Community Climate Model: CCM3. J. Climate, 11, 1131-1149.

Kutzbach, J. E., and H. E. Wright Jr., 1985: Simulation of the climate of 18,000 yr BP: Results for the North American/North Atlantic/ European sector. Quat. Sci. Rev., 4, 147-187.

— , P. J. Guetter, P. J. Behling, and R. Selin, 1993: Simulated climatic changes: Results of the COHMAP climate-model experiments. Global Climates Since the Last Glacial Maximum, H. E. Wright Jr. et al., Eds., University of Minnesota Press, 24-93.

Lemons, D. R., M. R. Milligan, and M. A. Chan, 1996: Paleoclimatic implications of late Pleistocene sediment yield rates for the Bonneville Basin, northern Utah. Palaeogeogr., Palaeoclimatol., Palaeoecol., 123, 147-159.

Li, J., T. K. Lowenstein, C. B. Brown, T.-L. Ku, and S. Luo, 1996: A $100 \mathrm{ka}$ record of water tables and paleoclimates from salt cores, Death Valley, California. Palaeogeogr., Palaeoclimatol., Palaeoecol., 123, 179-203.

Mahowald, N., K. Kohfeld, M. Hansson, Y. Balkanski, S. P. Harrison, I. C. Prentice, M. Schulz, and H. Rodhe, 1999: Dust sources and deposition during the last glacial maximum and current climate: A comparison of model results with paleodata from ice cores and marine sediments. J. Geophys. Res., 104, 15 895-15916.

Manabe, S., and A. J. Broccoli, 1985: The influence of continental ice sheets on the climate of an ice age. J. Geophys. Res., 90, 2167-2190.

Manley, W. F., and D. S. Kaufman, 2002: Alaska PaleoGlacier Atlas. Institute of Arctic and Alpine Research (INSTAAR), University of Colorado. [Available online at http://instaar.colorado.edu/ QGISL/ak_paleoglacier_atlas/apg_overview.html.]

Muhs, D. R., and M. Zárate, 2001: Late Quaternary eolian records of the Americas and their paleoclimatic significance. Interhemispheric Climate Linkages, V. Markgraf, Ed., Academic Press, 183-216.

— T. A. Ager, J. Been, J. Platt Bradbury, and W. E. Dean, 2003 A late Quaternary record of eolian silt deposition in a maar lake, St. Michael Island, western Alaska. Quat. Res., 60, 110-122.

Pan, Z., E. Takle, W. Gutowski, and R. Turner, 1999: Long simulation of regional climate as a sequence of short segments. Mon. Wea. Rev., 127, 308-321.

Peltier, W. R., 2002: On eustatic sea level history: Last Glacial Maximum to Holocene. Quat. Sci. Rev., 21, 377-396.

Polyak, L., M. H. Edwards, B. J. Coakley, and M. Jakobsson, 2001 Ice shelves in the Pleistocene Arctic Ocean inferred from glaciogenic deep-sea bedforms. Nature, 410, 453-457.

Powers, J. G., A. J. Monaghan, A. M. Cayette, D. H. Bromwich, Y.-H. Kuo, and K. W. Manning, 2003: Real-time mesoscale modeling over Antarctica: The Antarctic Mesoscale Prediction System (AMPS). Bull. Amer. Meteor. Soc., 84, 1533-1545.

Qian, J.-H., A. Seth, and S. E. Zebiak, 2003: Reinitialized versus continuous simulations for regional climate downscaling. Mon. Wea. Rev., 131, 2857-2874.

Reisner, J., R. M. Rasmussen, and R. T. Bruintjes, 1998: Explicit forecasting of supercooled liquid water in winter storms using the MM5 mesoscale model. Quart. J. Roy. Meteor. Soc., 124, 1071-1107.

Rind, D., 1987: Components of the ice age circulation. J. Geophys. Res., 92, 4142-4281.

_ 1988: Dependence of warm and cold climate depiction on climate model resolution. J. Climate, 1, 965-997.

Roe, G. H., and R. S. Lindzen, 2001: A one-dimensional model for the interaction between continental-scale ice sheets and atmospheric stationary waves. Climate Dyn., 17, 479-487.

Serreze, M., 1995: Climatological aspects of cyclone development and decay in the Arctic. Atmos.-Ocean, 33, 1-23.

_- F. Carse, and R. G. Barry, 1997: Icelandic low cyclone activity: Climatological features, linkages with the NAO, and relationships with recent changes in the Northern Hemisphere circulation. J. Climate, 10, 453-464.

Shinn, R. A., and E. J. Barron, 1989: Climate sensitivity to continental ice sheet size and configuration. J. Climate, 2, 1517-1537.

Street-Perrott, F. A., D. S. Marchand, N. Roberts and S. P. Harrison, 1989: Global lake-level variations from 18,000 to 0 years ago: A palaeoclimatic analysis. Tech. Rep., U.S. DOE/ER/60304-H1 TR046, U.S. Department of Energy, Washington, D.C., 213 pp.

Stute, M., P. Schlosser, J. F. Clark, and W. S. Broecker, 1992: Paleotemperatures in the southwestern United States derived from noble gases in ground water. Science, 256, 1000-1003.

_ _ _ P. Schlosser, W. S. Broecker, and G. Bonani, 1995: A 30,000 yr continental paleotemperature record derived from noble gases dissolved in groundwater from the San Juan Basin, New Mexico. Quat. Res., 43, 209-220.

Tarasov, L., and W. R. Peltier, 2004: A geophysically constrained large ensemble analysis of the deglacial history of the North American ice-sheet complex. Quat. Sci. Rev., 23, 359-388.

Thompson, R. S., and K. H. Anderson, 2000: Biomes of western North America at 18,000, 6000, and $0{ }^{14} \mathrm{C}$ yr BP reconstructed from pollen and packrat midden data. J. Biogeogr., 27, 555584.

_ C. C. Whitlock, P. J. Bartlein, S. P. Harrison, and W. G. Spaulding, 1993: Climatic changes in the western United States since 18,000 yr B.P. Global Climates Since the Last Glacial Maximum, H. E. Wright Jr. et al., Eds., University of Minnesota Press, 468-513.

Toracinta, E. R., R. J. Oglesby, and D. H. Bromwich, 2004: Atmospheric response to modified CLIMAP ocean boundary conditions during the Last Glacial Maximum. J. Climate, 17, 504522.

Williams, J. W., W. I. Thompson, P. H. Richard, and P. Newby, 2000: Late Quaternary biomes of Canada and the eastern United States. J. Biogeogr., 27, 585-607.

Yokoyama, Y., K. Lambeck, P. de Deckker, P. Johnson, and K. Fifield, 2000: Timing of the Last Glacial Maximum from observed sealevel minima. Nature, 406, 713-716. 